OPEN ACCESS

Edited by:

Jesse G. Dillon,

California State University,

Long Beach, United States

Reviewed by:

Anne Bernhard,

Connecticut College, United States

Jeremy Dodsworth,

California State University,

San Bernardino, United States

*Correspondence:

Annika C. Mosier

annika.mosier@gmail.com

Specialty section:

This article was submitted to

Extreme Microbiology,

a section of the journal

Frontiers in Microbiology

Received: 04 February 2017

Accepted: 19 October 2017

Published: 07 November 2017

Citation:

Ramanathan B, Boddicker AM,

Roane TM and Mosier AC (2017)

Nitrifier Gene Abundance

and Diversity in Sediments Impacted

by Acid Mine Drainage.

Front. Microbiol. 8:2136.

doi: 10.3389/fmicb.2017.02136

\section{Nitrifier Gene Abundance and Diversity in Sediments Impacted by Acid Mine Drainage}

\author{
Bhargavi Ramanathan, Andrew M. Boddicker, Timberley M. Roane and \\ Annika C. Mosier*
}

Department of Integrative Biology, University of Colorado Denver, Denver, CO, United States

Extremely acidic and metal-rich acid mine drainage (AMD) waters can have severe toxicological effects on aquatic ecosystems. AMD has been shown to completely halt nitrification, which plays an important role in transferring nitrogen to higher organisms and in mitigating nitrogen pollution. We evaluated the gene abundance and diversity of nitrifying microbes in AMD-impacted sediments: ammonia-oxidizing archaea (AOA), ammonia-oxidizing bacteria (AOB), and nitrite-oxidizing bacteria (NOB). Samples were collected from the Iron Springs Mining District (Ophir, CO, United States) during early and late summer in 2013 and 2014. Many of the sites were characterized by low $\mathrm{pH}(<5)$ and high metal concentrations. Sequence analyses revealed AOA genes related to Nitrososphaera, Nitrosotalea, and Nitrosoarchaeum; AOB genes related to Nitrosomonas and Nitrosospira; and NOB genes related to Nitrospira. The overall abundance of $\mathrm{AOA}, \mathrm{AOB}$ and $\mathrm{NOB}$ was examined using quantitative PCR (qPCR) amplification of the amoA and $n x r B$ functional genes and $16 S$ rRNA genes. Gene copy numbers ranged from $3.2 \times 10^{4}-4.9 \times 10^{7}$ archaeal amoA copies $* \mu \mathrm{g} \mathrm{DNA}^{-1}$, $1.5 \times 10^{3}-5.3 \times 10^{5}$ AOB 16 S rRNA copies $* \mu \mathrm{gNA}^{-1}$, and $1.3 \times 10^{6}-7.7 \times 10^{7}$ Nitrospira $n \times r B$ copies $* \mu \mathrm{g} \mathrm{DNA}^{-1}$. Overall, Nitrospira $n \times r B$ genes were found to be more abundant than AOB $16 \mathrm{~S}$ rRNA and archaeal amoA genes in most of the sample sites across 2013 and 2014. AOB 16S rRNA and Nitrospira nxrB genes were quantified in sediments with $\mathrm{pH}$ as low as 3.2, and AOA amoA genes were quantified in sediments as low as 3.5. Though $\mathrm{pH}$ varied across all sites $(\mathrm{pH}$ 3.2-8.3), $\mathrm{pH}$ was not strongly correlated to the overall community structure or relative abundance of individual OTUs for any gene (based on CCA and Spearman correlations). $\mathrm{pH}$ was positivity correlated to the total abundance (qPCR) of AOB 16S rRNA genes, but not for any other genes. Metals were not correlated to the overall nitrifier community composition or abundance, but were correlated to the relative abundances of several individual OTUs. These findings extend our understanding of the distribution of nitrifying microbes in AMD-impacted systems and provide a platform for further research.

Keywords: acid mine drainage, nitrification, ammonia-oxidizing archaea, ammonia-oxidizing bacteria, nitriteoxidizing bacteria 


\section{INTRODUCTION}

Nitrification, a central part of the nitrogen cycle, is globally important because it transfers nitrogen to higher organisms and mitigates nitrogen pollution when coupled with denitrification and anammox. Nitrification is the two-step aerobic oxidation of ammonia to nitrate through nitrite. Ammonia oxidation is mediated by ammonia-oxidizing archaea and bacteria (AOA and $\mathrm{AOB})$, while nitrite oxidation is mediated by nitrite-oxidizing bacteria (NOB) commonly from the Nitrobacter and Nitrospira lineages. Recent discoveries documented the complete oxidation of ammonia to nitrate (comammox) by Nitrospira (Daims et al., 2015; van Kessel et al., 2015). The microbial communities involved in ammonia oxidation and nitrite oxidation are commonly evaluated using 16S rRNA genes (Stephen et al., 1998) or functional markers such as the amoA gene (encoding the alpha subunit of the ammonia monooxygenase enzyme) (Stephen et al., 1999; Francis et al., 2005) and $n x r B$ gene (encoding the beta subunit of the nitrite oxidoreductase enzyme) (Pester et al., 2014). Many nitrifiers are obligate ammonia oxidizers or nitrite oxidizers (based on genomic sequences or physiology in culture), though some have mixotrophic capabilities (Ward et al., 2011; Hatzenpichler, 2012).

Nitrification has been documented in virtually every environment across the earth (e.g., soil, marine, freshwater) (Ward et al., 2011). Nonetheless, very little is known about nitrification in systems impacted by acid mine drainage (AMD), which refers to acidic and metal-rich waters that flow out of coal and metal mines. One study found that nitrification was completely halted in some AMD-impacted streams when $\mathrm{pH}$ dropped below 5.3 (Niyogi et al., 2003). However, it is unknown whether the findings are a general phenomenon in other streams or whether AMD differentially impacts the various groups of microorganisms involved in nitrification.

Though the impacts of AMD on nitrification are largely unknown, other research has evaluated individual environmental factors that are often associated with AMD, including acidic $\mathrm{pH}$ and high metal concentrations. Nitrification is impacted by acidic $\mathrm{pH}$, in part due to the reduced bioavailability of ammonia and nitrite at low pH (Suzuki et al., 1974; Stein et al., 1997). In some aquatic environments, overall nitrification rates were inhibited at $\mathrm{pH}$ values lower than 5.7-6 (Rudd et al., 1988; Huesemann et al., 2002). Small decreases in pH (by 0.05-0.14) reduced ammonia oxidation rates in the Atlantic and Pacific Oceans (Beman et al., 2011). In wastewater batch reactors, nitrite oxidation rates ceased at $\mathrm{pH}$ values lower than 6.5 (Jiménez et al., 2011). Nitrite oxidation rates by neutrophilic Nitrobacter and Nitrospira cultures significantly decreased below pH 6.5 (Ehrich et al., 1995; Grunditz and Dalhammar, 2001; Blackburne et al., 2007).

While acidic $\mathrm{pH}$ impacts the overall rates of ammonia oxidation and nitrite oxidation, some nitrifying microbes are capable of withstanding low $\mathrm{pH}$ conditions. AOA have been shown to be both abundant and active in some acidic soils, and often numerically dominate the AOB (e.g., Nicol et al., 2008; Gubry-Rangin et al., 2010, 2011; He et al., 2012; Zhang et al., 2012). Both AOA and AOB genes have been found in soils with
pH values as low as 3.8 (He et al., 2007; Hu et al., 2013; Lu and Jia, 2013). AOA amoA genes and transcripts have been detected in acidic fen soil pore water with $\mathrm{pH}$ values ranging from 4.6-4.9 (Herrmann et al., 2012). A small number of 16S rRNA gene sequences related to $\mathrm{AOA}$ were described in an acid pit lake and in AMD sediments with pH 2-3.5 (Volant et al., 2012; Lucheta et al., 2013). Two acidophilic AOA cultured from soils showed growth at $\mathrm{pH}$ ranging from 4.0-6.1 (Lehtovirta-Morley et al., 2011, 2014).

High concentrations of metals in AMD-impacted systems may also affect nitrification, as has been shown in other environments. Heavy metals, such as copper, zinc, lead, cadmium, nickel, and metal sulfides, are associated with decreased nitrification rates in soils and freshwater sediments (Wilson, 1977; Broberg, 1984; Smolders et al., 2001; Cela and Sumner, 2002). Studies have demonstrated that $\mathrm{AOA}$ and $\mathrm{AOB}$ respond differently to heavy metals: AOA seemed more tolerant to copper and arsenic contamination than AOB in soils (Li et al., 2009; Subrahmanyam et al., 2014); however, $\mathrm{AOB}$ were more active than AOA in zinc contaminated soils (Mertens et al., 2009). The mechanism of metal resistance in ammonia oxidizers and nitrite oxidizers is largely unknown; however, metal resistance genes (e.g., copper, mercury, arsenic, zinc resistance) have been found in some nitrifiers, including Nitrosomonas eutropha, Nitrososphaera gargensis, Nitrospira defluvii, and Nitrobacter hamburgensis (Stein et al., 2007; Starkenburg et al., 2008; Lücker et al., 2010; Spang et al., 2012).

In the Colorado Rocky Mountains, AMD is a particularly common threat due to the large number of mines in the area. In the present study, we used high-throughput sequencing and quantitative PCR (qPCR) to examine the abundance and diversity of $\mathrm{AOA}, \mathrm{AOB}$, and NOB in AMD-impacted sediments in the Iron Springs Mining District near Ophir, CO, United States.

\section{MATERIALS AND METHODS}

\section{Site Description and Sample Collection}

The Iron Springs Mining District located in Ophir, CO, United States consists of several abandoned mines. From 1877 to 1960, the Iron Springs Mining District was predominantly mined for metals such as silver, gold and lead, and also to some extent for iron (pigment) and tungsten (Nash, 2002). AMD from these mines drains directly into the Howard Fork River. Composite sediment samples (shoveled from the surface to a depth of approximately five centimeters) were collected from 11 sampling sites during June and August 2013 (Sackett and Roane, Master's Thesis, University of Colorado, Denver, CO, United States), and from 10 sampling sites during June and September 2014 at Iron Springs (Figure 1 and Supplementary Figure S1). Sediment samples for DNA extracts were stored on dry ice until permanent storage at $-20^{\circ} \mathrm{C}$ in the laboratory freezer. For total recoverable metal (TRW) analysis, $500 \mathrm{~mL}$ of surface water sample was collected, acidified to $\mathrm{pH}<2$ with concentrated nitric acid and stored at $4^{\circ} \mathrm{C}$. For dissolved metal (DM) analysis, $500 \mathrm{~mL}$ of surface water sample was collected, filtered with a cellulose nitrite membrane filter (Thermo Scientific, Waltham, MA), 


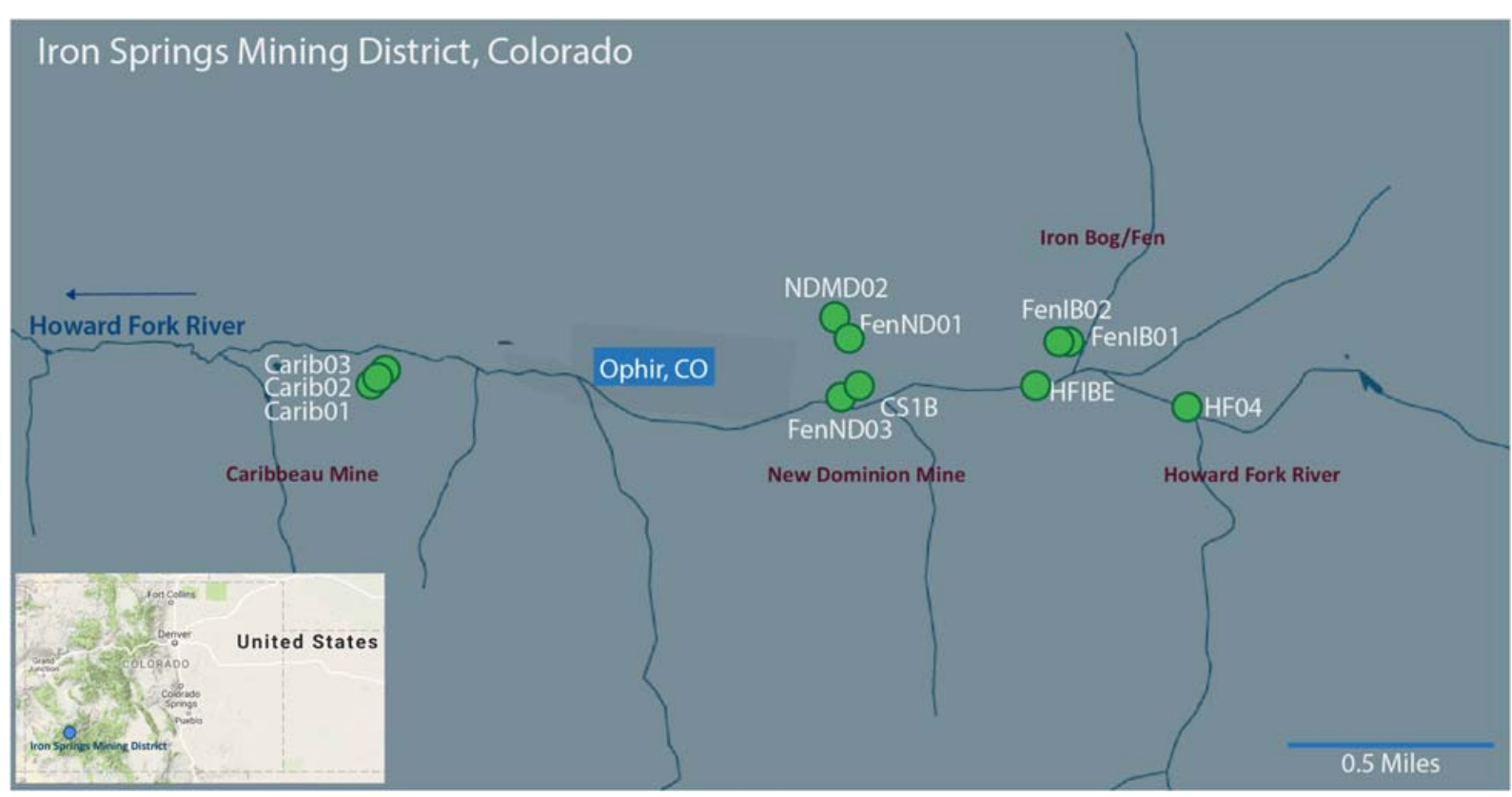

FIGURE 1 | Map of the study sites within the Iron Springs Mining District near Ophir, Colorado. Individual sample sites are denoted with a green circle. Sampling regions are denoted in purple. Arrow indicates the direction of flow for the Howard Fork River. Base images modified from Google Maps (Map data @ Google 2015 and (C) Google 2017).

acidified to $\mathrm{pH}<2$ with concentrated nitric acid and stored at $4^{\circ} \mathrm{C}$.

\section{Environmental Parameters}

Temperature, $\mathrm{pH}$, conductivity, and dissolved oxygen were measured at the sediment surface using a Thermo Scientific Orion 5-Star Multiparameter Meter Kit (Thermo Fisher Scientific, Inc., Waltham, MA, United States) and an In Situ Multiparameter meter. Metal analyses (TRW and DM) of the Iron Springs water samples were done at the EPA Region 8 lab (Golden, CO, United States) using Inductively-Coupled Plasma Mass Spectrometry (ICP-MS) following EPA method 200.8, and Inductively-Coupled Plasma Optical Emission Spectrometry (ICP-OES) following EPA method 200.7. The analytes measured for TRW and DM included aluminum ( $\mathrm{Al}$ ), antimony $(\mathrm{Sb})$, arsenic (As), barium (Ba), cadmium (Cd), calcium (Ca), copper $(\mathrm{Cu})$, iron $(\mathrm{Fe})$, lead $(\mathrm{Pb})$, magnesium $(\mathrm{Mg})$, manganese $(\mathrm{Mn})$, nickel $(\mathrm{Ni})$, selenium $(\mathrm{Se})$, silver $(\mathrm{Ag})$, sodium $(\mathrm{Na})$, strontium $(\mathrm{Sr})$, thallium $(\mathrm{Tl})$, vanadium $(\mathrm{V})$ and $\operatorname{zinc}(\mathrm{Zn})$.

\section{DNA Extraction}

The PowerMax Soil DNA Isolation Kit (MO BIO Laboratories, Inc., Carlsbad, CA, United States) was used to isolate total DNA from subsamples of mechanically homogenized saturated composite sediment $(\sim 10 \mathrm{~g})$ from each sample site. DNA extracts were quantified using the Qubit dsDNA HS Assay Kit with the Qubit 2.0 Fluorometer (Life Technologies Corporation, Carlsbad, CA, United States). High quality samples $(n=38)$ based on gel electrophoresis, DNA quantification, and PCR amplification were selected for further analyses (excluded samples were
HF04-June14; HF04-Sept14; FenND03-Jun13; FenND03-Sept14; FenIB02-Sept14; Carib01-June14).

\section{Quantification of Gene Abundance}

$\mathrm{AOA}, \mathrm{AOB}$, and $\mathrm{NOB}$ genes were quantified using the StepOnePlus Real-Time PCR system (Life Technologies Corporation). AOA amoA genes were quantified using the primers Arch-amoAF and Arch-amoAR (Francis et al., 2005). AOB were quantified using AOB-specific 16S rRNA gene primers NitA and CTO654r (Voytek and Ward, 1995; Kowalchuk et al., 1997; Sonthiphand et al., 2013). AOB amoA genes did not amplify in our samples using primers amoA-1F/amoA-2R (Rotthauwe et al., 1997) or amoA-1F*/amoA-2R (Stephen et al., 1999). Nitrospira $n \times r B$ genes were quantified using the primers nxrB169F and nxrB638R (Pester et al., 2014). Three primer sets were used in an attempt to amplify Nitrobacter genes: $n x r B$ gene primers nxrB-1F/nxrB-1R (Vanparys et al., 2007), Nitrobacterspecific 16S rRNA gene primers Nitro-1198f/Nitro-1423r (Graham et al., 2007; Huang et al., 2010), and Nitrobacter-specific 16S rRNA gene primers FGPS872f/FGPS1269r (Degrange and Bardin, 1995).

qPCR conditions and reactions (with modifications pertaining to the current study) were carried out as previously described for archaeal amoA (Mosier and Francis, 2008), and for AOB 16S rRNA (Sonthiphand et al., 2013) with the addition of a plate read step at $81^{\circ} \mathrm{C}$ for $10 \mathrm{~s}$ at the end of each cycle. The previously described PCR conditions for Nitrospira nxrB (Pester et al., 2014) were applied to qPCR with the addition of a plate read step at $84^{\circ} \mathrm{C}$ for $10 \mathrm{~s}$ at the end of each cycle. The reactions were performed in a $20 \mu \mathrm{l}$ reaction mixture with $1 \mu \mathrm{l}$ of template 
DNA, $0.4 \mu \mathrm{l}$ of $25 \mu \mathrm{M}$ passive reference dye, and the following for the respective primer pairs: $10 \mu \mathrm{l}$ of Failsafe Green Premix E (Epicentre, Madison, WI, United States), $2 \mathrm{mM}$ of $\mathrm{MgCl}_{2}$, $0.4 \mu \mathrm{M}$ of each primer, $40 \mathrm{ng} * \mu \mathrm{l}^{-1}$ of BSA, and 1 Unit of AmpliTaq DNA Polymerase (Applied Biosystems, Foster City, CA, United States) for archaeal amoA; $10 \mu \mathrm{l}$ of Failsafe Green Premix F (Epicentre, Madison, WI, United States), $0.3 \mu \mathrm{M}$ of each primer, $19.8 \mathrm{ng} * \mu \mathrm{l}^{-1}$ of BSA, and 1 Unit of AmpliTaq DNA polymerase (Applied Biosystems, Foster City, CA, United States) for AOB 16S rRNA; and $10 \mu$ l of Failsafe Green Premix F (Epicentre, Madison, WI, United States), $1 \mu \mathrm{M}$ of each primer, and 0.5 Units of AmpliTaq DNA polymerase (Applied Biosystems, Foster City, CA, United States) for Nitrospira nxrB. The amount of DNA used in each reaction ranged from 0.32 to $53.3 \mathrm{ng}$ of DNA for all samples (average was $11.9 \mathrm{ng}$ per reaction; two samples had $<1 \mathrm{ng}$ ).

Standard curves for the 16S rRNA assay were generated using linearized plasmid DNA from a cloned Iron Springs AOB $16 \mathrm{~S}$ rRNA gene sequence. Standards for the archaeal amoA and Nitrospira $n \times r B$ assays were generated by gene synthesis (Life Technologies Corporation) from Nitrosoarchaeum limnia SFB1 amo $A$ and Nitrospira defluvii $n \times r B$ sequences. The standard gene copies for the assays ranged from $13-1.2 \times 10^{7}$ for archaeal amoA, $16-3.3 \times 10^{7}$ for AOB $16 \mathrm{~S}$ rRNA, and $15-1.5 \times 10^{7}$ for Nitrospira $n \times r B$. Duplicate or triplicate reactions were carried out for all the samples and standards, and average values were calculated. Melt curves were generated after each SYBR assay to check the specificity of amplification. For the standard curves, PCR efficiencies averaged 79-91\% and the correlation coefficients $\left(R^{2}\right)$ were $>0.99$. Samples that amplified but fell below the lowest standard (e.g., <13 copies for archaeal amoA) were identified as "below detection limit." "Non-specific amplification" was identified in the melt curve analysis.

\section{Illumina MiSeq Library Preparation}

DNA extracts were sent to the University of Illinois Roy J. Carver Biotechnology Center, Urbana, Illinois, United States for amplicon sequencing on the Illumina MiSeq sequencing platform. Library preparation was completed with the Fluidigm 48.48 Access Array IFC platform (Fluidigm Corporation, South San Francisco, CA, United States) to amplify the products from eight different PCR primer sets: Arch349F/Arch806R for archaeal 16S rRNA (Takai and Horikoshi, 2000), V4_515F/926R for total 16S rRNA (Parada et al., 2016), NitA/CTO654R for AOB 16S rRNA (Voytek and Ward, 1995; Kowalchuk et al., 1997; Sonthiphand et al., 2013), FGPS872F/FGPS1269R for Nitrobacter 16S rRNA (Degrange and Bardin, 1995), nxrB169F/nxrB638R for Nitrospira nxrB (Pester et al., 2014), and Arch_amoAF/Arch_amoAR for archaeal amoA (Francis et al., 2005). The sequencing center validated each primer set to ensure amplification under the given reaction conditions prior to sequencing.

Samples were diluted to a final concentration of $2 \mathrm{ng} * \mu \mathrm{L}^{-1}$. A mastermix was prepared with Roche (Basel, Switzerland) High Fidelity Fast Start Kit and 20x Access Array loading reagent according to Fluidigm protocols. Into each well of a PCR plate, $1 \mu \mathrm{L}$ of each sample was mixed with $1 \mu \mathrm{L}$ of Fluidigm Illumina linkers and unique barcodes mix, $0.5 \mu \mathrm{L}$ of $10 \mathrm{X}$ FastStart Reaction Buffer without $\mathrm{MgCl}_{2}, 0.9 \mu \mathrm{L}$ of $25 \mathrm{mM} \mathrm{MgCl}_{2}, 0.25 \mu \mathrm{L}$ of DMSO, $0.1 \mu \mathrm{L}$ of $10 \mathrm{mM}$ PCR grade nucleotide mix, $0.05 \mu \mathrm{L}$ of $5 \mathrm{U} * \mu \mathrm{L}^{-1}$ FastStart High Fidelity enzyme blend, $0.25 \mu \mathrm{L}$ of $20 \mathrm{X}$ Access Array Loading Reagent, and $0.95 \mu \mathrm{L}$ of water. In a separate plate, 20X primer solutions were prepared by adding $2 \mu \mathrm{L}$ of each forward and reverse primer (synthesized by IDT Corp, Coralville, IA, United States), $5 \mu \mathrm{L}$ of $20 \mathrm{X}$ Access Array Loading Reagent, and $91 \mu \mathrm{L}$ of water.

Once the sample mixture was complete, $4 \mu \mathrm{L}$ was loaded into the sample inlets and $4 \mu \mathrm{L}$ of the primer solution was loaded into the primer inlets of a primed Fluidigm 48.48 Access Array IFC. The IFC was then placed in a Fluidigm AX controller for microfluidic mixing of each primer and sample combination before being loaded into the Fluidigm Biomark HD PCR machine. Amplicons were generated using the following Access Array cycling program without imaging: $50^{\circ} \mathrm{C}$ for $2 \mathrm{~min}$, $70^{\circ} \mathrm{C}$ for $20 \mathrm{~min}, 95^{\circ} \mathrm{C}$ for $10 \mathrm{~min} ; 10$ cycles of $95^{\circ} \mathrm{C}$ for $15 \mathrm{~s}, 60^{\circ} \mathrm{C}$ for $30 \mathrm{~s}$, and $72^{\circ} \mathrm{C}$ for $1 \mathrm{~min} ; 2$ cycles of $95^{\circ} \mathrm{C}$ for $15 \mathrm{~s}, 80^{\circ} \mathrm{C}$ for $30 \mathrm{~s}, 60^{\circ} \mathrm{C}$ for $30 \mathrm{~s}$, and $72^{\circ} \mathrm{C}$ for $1 \mathrm{~min} ; 8$ cycles of $95^{\circ} \mathrm{C}$ for $15 \mathrm{~s}$, $60^{\circ} \mathrm{C}$ for $30 \mathrm{~s}$, and $72^{\circ} \mathrm{C}$ for $1 \mathrm{~min} ; 2$ cycles of $95^{\circ} \mathrm{C}$ for $15 \mathrm{~s}, 80^{\circ} \mathrm{C}$ for $30 \mathrm{~s}, 60^{\circ} \mathrm{C}$ for $30 \mathrm{~s}$, and $72^{\circ} \mathrm{C}$ for $1 \mathrm{~min} ; 8$ cycles of $95^{\circ} \mathrm{C}$ for $15 \mathrm{~s}, 60^{\circ} \mathrm{C}$ for $30 \mathrm{~s}$, and $72^{\circ} \mathrm{C}$ for $1 \mathrm{~min}$; and 5 cycles of $95^{\circ} \mathrm{C}$ for $15 \mathrm{~s}, 80^{\circ} \mathrm{C}$ for $30 \mathrm{~s}, 60^{\circ} \mathrm{C}$ for $30 \mathrm{~s}$, and $72^{\circ} \mathrm{C}$ for $1 \mathrm{~min}$.

After amplification, $2 \mu \mathrm{L}$ of Fluidigm Harvest Buffer was added to each sample inlet, and the IFC loaded onto the AX controller to harvest all PCR products from each sample (e.g., all primer amplifications pooled together for each sample). The PCR products were quantified using Qubit and stored at $-20^{\circ} \mathrm{C}$. The samples were run on a Fragment Analyzer (Advanced Analytics, Ames, IA, United States) to confirm the expected sizes of amplicons. All of the 48 samples (containing all primer amplifications pooled together) were then pooled together in equal DNA concentrations into one tube. The pooled product was size selected on a $2 \%$ E-gel (Life Technologies Corporation), then recovered based on expected fragment size with a Qiagen (Hilden, Germany) gel extraction kit. Cleaned, size-selected products were run on an Agilent Bioanalyzer to confirm the expected profile and determine the average product size.

The size-selected pool was qPCR quantitated and loaded onto one MiSeq flowcell using a MiSeq 600-cycle sequencing kit, version 3 for 300 bp paired-end sequencing using a MiSeq FGx system in RUO mode. After sequencing, read data was translated into FASTQ files using the Illumina bcl2fastq 1.8.4 software with an ASCII offset of 33. PhiX DNA reads (used as a spike-in control) were removed by alignment to the PhiX genome. The Roy J. Carver Biotechnology Center used in-house scripts for sorting the reads (with two mismatches allowed in the $5^{\prime}$ primer sequences) and demultiplexing (with one mismatch allowed in the index sequence attached in library prep).

\section{Sequence Controls}

Sequence reads were evaluated for each gene set in a no-template control sample (nuclease free water). A total of 24 Bacterial 16S rRNA OTUs were found in the blank, all of which were related to Pseudomonas. One of these OTUs had 7,000 sequence reads (compared to $>15,000$ reads for all of the AMD samples), 
but all other OTUs had low read counts (2-186 reads per OTU). No Archaeal 16S rRNA, AOA amoA, or Nitrospira nxrB OTUs were present in the blank. One sample (Carib03Sept14) was sequenced twice to evaluate reproducibility. Bacterial $16 \mathrm{~S}$ rRNA gene community membership and relative abundance were highly correlated $\left(R^{2}>0.99\right)$ between the replicate samples.

\section{Community Composition Analyses}

Relative sequence abundance and diversity analyses were conducted using QIIME (Quantitative Insights into Microbial Ecology) (Caporaso et al., 2010) and UPARSE (Edgar, 2013). The paired-ends were joined and quality filtered at Phred quality score of 20. Singletons were removed with the min_count_fraction option in QIIME. Sequences with minimum merge length $<80 \mathrm{bp}$ were discarded and the last $20 \mathrm{bp}$ were removed from both ends. Analyses for archaeal $a m o A$ were done based on sequencing read one due to the lack of overlap between read one and read two (gene amplicon length: $635 \mathrm{bp}$ ). Sequencing reads were clustered into operational taxonomical units (OTUs) at $97 \%$ sequence identity. For $16 \mathrm{~S}$ rRNA genes, the final OTUs were checked for chimeras using the DECIPHER web tool with the short sequences option (Wright et al., 2012) and putative chimeras were removed from the OTU table. Taxonomy of OTUs was assigned using a BLAST-based method with the Greengenes 13_8 rep set database (DeSantis et al., 2006) for 16S rRNA and NCBI database for functional genes. For further analyses, the final OTUs were filtered for specific taxa: the class Thaumarchaeota was filtered from the Archaeal 16S rRNA reads, the order Nitrosomonadales was filtered from the AOB 16S rRNA reads (no other AOB sequences were identified in the dataset), and Bacteria were filtered from the total $16 \mathrm{~S}$ rRNA reads.

The number of observed OTUs for each gene was determined using QIIME. The sequence threshold cutoffs were set to 15,680 sequences for the combined V4-V5 region of bacterial $16 \mathrm{~S}$ rRNA, 650 sequences for Nitrosomonadales taxa-specific AOB $16 \mathrm{~S}$ rRNA, 60 sequences for archaeal 16S rRNA, 60 sequences for Thaumarchaeota taxa-specific archaeal 16S rRNA, 70 sequences for archaeal amoA, and 500 sequences for Nitrospira nxrB (low sequence thresholds were set in order to maximize OTU recovery). Rarefaction was performed at multiple sequence depths between one and the rarified depth (set to the median number of sequences for each gene). Chaol richness estimates were determined at rarified depth for each gene.

\section{Phylogenetic Analyses}

Representative sequences of the observed OTUs were aligned and sequences with short length, internal stop codons, or misalignments were removed. The Nitrospira nxrB OTUs were aligned to the curated alignment created by Pester et al. (2014) using ARB (Ludwig, 2004). The alignment length for each gene was 260 bp for archaeal amoA, 480 bp for AOB 16S rRNA, and 445 bp for Nitrospira nxrB. Maximum Likelihood trees were constructed for representative sequences of observed OTUs using FastTree v2.1.5 package (Price et al., 2010) in Geneious v8.1.8 (Kearse et al., 2012), with Jukes-Cantor Correction and 100 bootstrap replicates. Although significant bootstrap values $(>50)$ occurred at the majority of the major branching points, values were not plotted on the phylogenetic trees due to the limitations of phylogenetic analyses with short gene sequences. Trees were visualized using the Interactive Tree of Life (iTOL) (Letunic and Bork, 2016). The normalized average relative abundance was plotted for each OTU (OTU relative abundance averaged by region, then divided by the sum of the averages for all regions).

\section{Statistical Analyses}

Spearman correlation between environmental parameters and total gene abundances (based on qPCR) was performed using the IBM SPSS Statistics software package version 23 (IBM, Armonk, NY, United States) with critical $p$-values $(\alpha)$ corrected using Bonferroni correction (the adjusted significant $\alpha$-value was set to $\leq 0.00156$ ). Spearman correlations between environmental parameters and the relative abundance of individual OTUs were carried out using QIIME (observation_metadata_correlation.py) with $p$-values corrected using the Bonferroni correction. The environmental parameters from surface sediments included in the statistical analyses were: $\mathrm{pH}$, temperature $\left({ }^{\circ} \mathrm{C}\right)$, conductivity $\left(\mu \mathrm{S} * \mathrm{~cm}^{-1}\right)$ and dissolved oxygen $\left(\mathrm{mg} * \mathrm{~L}^{-1}\right)$. Environmental parameters from surface water included in statistical analyses were: TRW (in $\mu \mathrm{g} * \mathrm{~L}^{-1}$ ) including $\mathrm{Al}, \mathrm{As}, \mathrm{Ba}, \mathrm{Cd}, \mathrm{Ca}, \mathrm{Cu}, \mathrm{Fe}, \mathrm{Pb}$, $\mathrm{Mg}, \mathrm{Mn}, \mathrm{Ni}, \mathrm{Na}, \mathrm{Sr}, \mathrm{Tl}$, and $\mathrm{Zn}$; and $\mathrm{DM}$ (in $\mu \mathrm{g} * \mathrm{~L}^{-1}$ ) including $\mathrm{Al}, \mathrm{Ba}, \mathrm{Cd}, \mathrm{Ca}, \mathrm{Cu}, \mathrm{Fe}, \mathrm{Pb}, \mathrm{Mg}, \mathrm{Mn}, \mathrm{Ni}, \mathrm{Na}, \mathrm{Sr}$ and $\mathrm{Zn}$.

Correlations between nitrifier community composition (AOA amoA, AOB $16 \mathrm{~S}$ rRNA, and Nitrospira nxrB genes) and environmental parameters were analyzed using canonical correspondence analysis (CCA) with the Canoco 5 v. 5.04 (Šmilauer and Lep̌s, 2014). Relative abundance of OTUs was used as the species input. Environmental variables included in the analyses were $\mathrm{pH}$, conductivity, temperature, dissolved oxygen, and TRW for $\mathrm{Al}, \mathrm{Ca}, \mathrm{Fe}, \mathrm{Pb}, \mathrm{Mg}, \mathrm{Mn}, \mathrm{Na}, \mathrm{Sr}, \mathrm{Zn}$ (dissolved metals were removed because of the covariation with total metals). Significant environmental variables were determined through forward selection with adjusted $p$-values (Bonferroni Correction).

\section{Nucleotide Sequence Accession Numbers}

Sequences reported in this study have been deposited in GenBank under accession numbers KY938713-KY938805; KY940445KY940462; and KY942196-KY944567.

\section{RESULTS}

\section{Chemistry}

Sample sites covered four different mines/regions within the greater Iron Springs Mining District: Caribbeau Mine (Carib01, Carib02 and Carib03), Iron Bog/Fen (FenIB01, FenIB02, HFIBE and Opp03), New Dominion Mine (FenND01, FenND03, NDMD02, NDCS02, CS1B and NDGP), and Howard Fork River (HF04) (Figure 1). The measured environmental parameters varied by sampling date and sampling location (Supplemental Tables S1, S2). Across surface sediments from all the sites in 2013 and 2014 , temperature ranged from $7.1^{\circ} \mathrm{C}-21.2^{\circ} \mathrm{C}$, dissolved 
oxygen ranged from $1.1-10 \mathrm{mg} * \mathrm{~L}^{-1}$, and $\mathrm{pH}$ ranged from $3.2-$ 8.3. The lowest $\mathrm{pH}$ was measured at the CS1B site in June of 2013 and 2014 ( $\mathrm{pH}$ 3.2). The Caribbeau Mine sites had circumneutral $\mathrm{pH}$ at all time points ( $\mathrm{pH} 7.3$ on average).

Metal concentrations from surface water (TRW and DM) were measured for all samples sites and time points (Supplementary Tables S1, S2). The sediments contained high concentrations of metals commonly found in AMD environments including cadmium, copper, iron, lead, and zinc. Overall, New Dominion Mine sites had the highest average metal concentrations for $100 \%$ of the metals in 2013 and $80 \%$ of the metals in 2014, including Ca, $\mathrm{Fe}, \mathrm{Mg}, \mathrm{Mn}, \mathrm{Na}, \mathrm{Sr}$, and $\mathrm{Zn}$ (for metals measured in at least $80 \%$ of the samples).

\section{Gene Abundance of $A O A, A O B$, and NOB}

The overall abundance of AOA, AOB, and NOB genes was determined across a total of 38 AMD-impacted sites from June 2013, August 2013, June 2014, and September 2014 from the Iron Springs Mining District (Figure 2 and Supplementary Table S3). Gene abundance showed a clear seasonal pattern: AOA, AOB, and NOB genes were more abundant in late summer than in early summer $(\sim 5$ times more abundant in late summer for $\sim 80 \%$ of samples where abundance was measured in both time points for a given year).

Archaeal amoA gene copies across 2013 and 2014 ranged from $3.2 \times 10^{4}-4.9 \times 10^{7}$ copies $* \mu \mathrm{g} \mathrm{DNA}^{-1}$ (Figure 2A). Archaeal $a m o A$ genes were most abundant in the Iron Bog/Fen sites (HFIBE and FenIB01) during both 2013 and 2014, ranging from $5.4 \times 10^{5}-4.9 \times 10^{7}$ copies $* \mu \mathrm{g} \mathrm{DNA}^{-1}$. Archaeal $a m o A$ gene copy numbers were lowest at the New Dominion Mine FenND03 site in 2013 with $4.8 \times 10^{4}$ copies $* \mu \mathrm{g} \mathrm{DNA}^{-1}$, with a $\sim 1,000$-fold difference when compared to the most abundant sites.

Ammonia-oxidizing bacteria were quantified using AOBspecific 16S rRNA gene primers since $\mathrm{AOB} a m o A$ genes did not amplify in our samples [using primers amoA-1F/amoA-2R (Rotthauwe et al., 1997) or amoA-1F*/amoA-2R (Stephen et al., 1999)]. The overall abundance of AOB $16 \mathrm{~S}$ rRNA genes across 2013 and 2014 samples sites ranged from $1.5 \times 10^{3}-5.3 \times 10^{5}$ copies $* \mu \mathrm{g} \mathrm{DNA}^{-1}$ (Figure 2B). During 2013 and 2014, the AOB 16S rRNA genes were most abundant in the Caribbeau Mine sites, ranging from $3.5 \times 10^{3}-5.3 \times 10^{5}$ copies/ $\mu$ g DNA. The AOB $16 \mathrm{~S}$ rRNA gene copy numbers were lowest at the New Dominion Mine sites (FenND01 and FenND03, 2013) with $1.5 \times 10^{3}$ copies $* \mu \mathrm{g} \mathrm{DNA}^{-1}$.

The qPCR results indicated that archaeal amo $A$ genes were more abundant than AOB 16S rRNA genes at most sites and time points, which may suggest that AOA are more abundant than AOB since both genes are thought to exist in single copies within each genome (Aakra et al., 1999; Kowalchuk and Stephen, 2001; Hermansson and Lindgren, 2001; Hallam et al., 2006; Norton et al., 2008). Archaeal $a m o A$ genes were more abundant than AOB $16 \mathrm{~S}$ rRNA genes in $100 \%$ of the samples where both genes amplified ( $n=22 ; 100$ times more abundant on average).

Nitrospira $n \times r B$ gene copies ranged from $1.3 \times 10^{6}-7.7 \times 10^{7}$ copies $* \mu \mathrm{g} \mathrm{DNA}^{-1}$ across 2013 and 2014 (Figure 2C). During
2013, Nitrospira nxrB genes were most abundant at the Howard Fork River sites ranging from $1.6 \times 10^{7}-2.9 \times 10^{7}$ copies $*$ $\mu \mathrm{g} \mathrm{DNA}^{-1}$ and Caribbeau Mine sites ranging from $5.3 \times 10^{6}$ $2.8 \times 10^{7}$ copies $* \mu \mathrm{g} \mathrm{DNA}^{-1}$. In 2014, Nitrospira $n \times r B$ genes were most abundant at the Iron Bog/Fen sites (FenIB01 and HFIBE) ranging from $3.8 \times 10^{7}-7.7 \times 10^{7}$ copies $* \mu \mathrm{g} \mathrm{DNA}^{-1}$ followed by Caribbeau Mine sites (Carib02 and Carib03) ranging from $8.8 \times 10^{6}-6.5 \times 10^{7}$ copies $* \mu \mathrm{g} \mathrm{DNA}^{-1}$. Nitrospira $n \times r B$ gene copy numbers were the lowest at New Dominion Mine sites $\left(1.3 \times 10^{6}-3.8 \times 10^{7}\right.$ copies $\left.* \mu \mathrm{g} \mathrm{DNA}^{-1}\right)$ when compared across all sample regions during 2013 and 2014.

Nitrobacter genes did not amplify in any of the samples using nxrB-1F/nxrB-1R primers (Vanparys et al., 2007), Nitrobacterspecific 16S rRNA gene primers Nitro-1198f/Nitro-1423r (Huang et al., 2010), or Nitrobacter-specific 16S rRNA gene primers FGPS872f/FGPS1269r (Degrange and Bardin, 1995).

\section{Relative Abundance, Richness, and Phylogeny}

Sequence analyses revealed that bacterial 16S rRNA genes were related to Proteobacteria (47\%), Bacteroidetes (10\%), Chloroflexi (9\%), Acidobacteria (8\%), and Actinobacteria (7\%). Nitrospira accounted for $0.4 \%$ and Nitrosomonadaceae accounted for $<0.1 \%$ of the total bacterial 16S rRNA community. No Nitrobacter sequences were found in the bacterial 16S rRNA gene dataset. A total of 2286 unique bacterial 16S rRNA gene OTUs were identified (at 97\% sequence identity), with 181-1291 OTUs observed within each sample (Supplementary Figures S2A, S3A). Chaol richness estimates ranged from 209 - 1384 OTUs for each sample.

The archaeal 16S rRNA gene sequences were related to the phyla Crenarchaeota (58\%) including the Thaumarchaeota (42\%), Euryarchaeota (16\%), and Parvarchaeota (26\%). A total of 66 unique archaeal 16S rRNA gene OTUs were identified, with 1-22 OTUs observed within each sample (Supplementary Figures S2B, S3B). Chao1 richness estimates ranged from $1-20$ OTUs for each sample.

For archaeal amoA genes, 18 OTUs were recovered across all samples, with 2-10 OTUs observed within each sample (Figure 3A and Supplementary Figure S3C). Chaol richness estimates ranged from $1-9$ OTUs for each sample at their highest sequencing depths. The 18 observed OTUs were phylogenetically related to Nitrosoarchaeum (5 OTUs), Nitrosotenuis (1 OTU), Nitrosotalea (6 OTUs), and soil clones that had $82.7 \%$ sequence identity to Nitrososphaeara (6 OTUs) (Figure 4 and Supplementary Table S4). Five OTUs (OTU $3,2,5,17$, and 19) were present at all four sampling site regions. Six OTUs were observed only in one region (OTU 10,12 , and 15 found only at the Iron Bog/Fen sites; OTU 14 found only at the Caribbeau Mine site; and OTU 9 and 11 found only at the New Dominion Mine sites). The remaining 7 OTUs were found in two or three sampling regions. For Thaumarchaeota 16S rRNA genes (filtered from the total Archaeal 16S rRNA gene set), 8 OTUs were recovered across all samples, with 1-5 OTUs observed within each sample (Figure 3B, Supplementary Figure S3D and Table S5). Chao1 


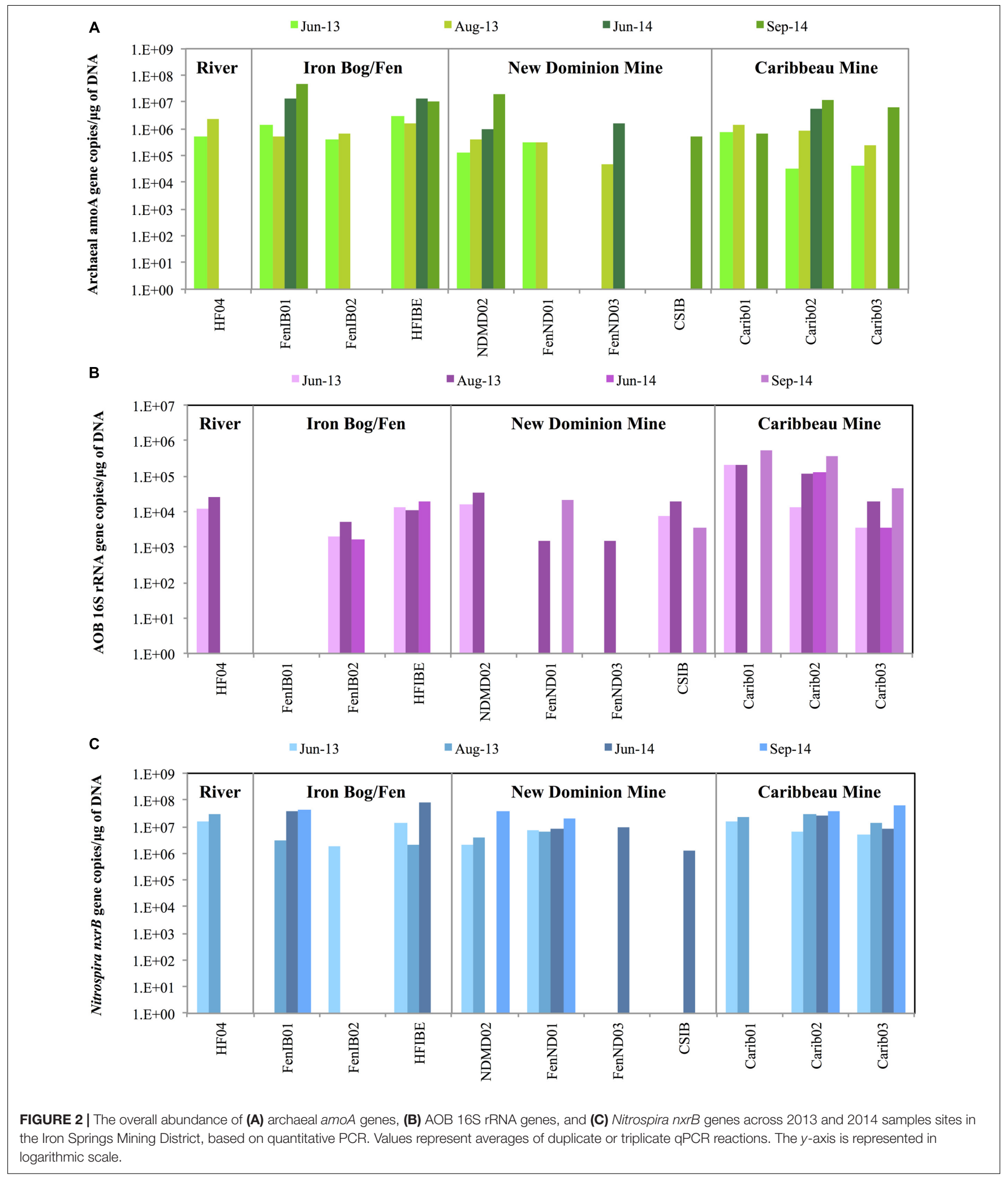

richness estimates ranged from $1-5$ OTUs for each sample at their highest sequencing depths. The observed Thaumarchaeota $16 \mathrm{~S}$ rRNA gene OTUs had highest nucleotide identity to uncultured archaeal clones (based on BLAST), and ranged from 80 to $94 \%$ nucleotide identity to Nitrosopumilus maritimus-the first cultured AOA. 


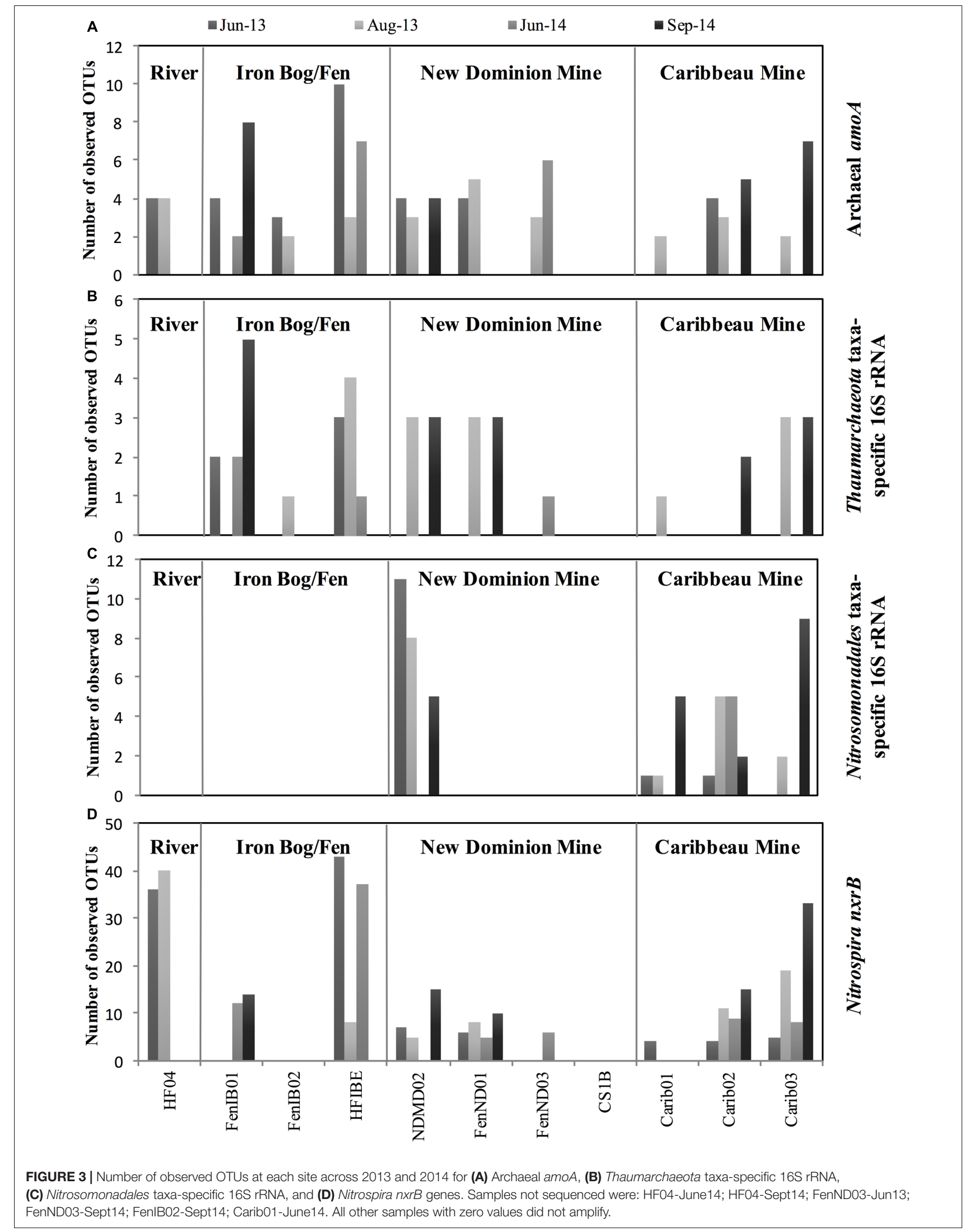


A total of 20 unique AOB 16S rRNA gene OTUs were recovered belonging to the order Nitrosomonadales, with 1-11 OTUs observed within each sample (Figure 3C and Supplementary Figure S3E). Chaol richness estimates ranged from 1 - 10 OTUs for each sample. These OTUs were only found in two regions: New Dominion Mine and Caribbeau Mine. In all cases, relative abundance within an OTU was far greater at one region over the other ( $>97 \%$ normalized relative abundance), with 11 OTUs dominating at New Dominion Mine and 9 OTUs dominating at Caribbeau Mine. Phylogenetic analyses indicated that the New Dominion Mine OTUs were only associated with Nitrosomonas (Figure 5 and Supplementary Table S6). Several OTUs were closely related to a cluster of sequences found in low nutrient environments. Caribbeau Mine OTUs were related to Nitrosospira and Nitrosomonas (Figure 5).

Nitrospira $n \times r B$ sequences had the highest number of observed OTUs (compared to AOA and $\mathrm{AOB}$ ), with a total of 93 unique OTUs and 4-43 OTUs found at each individual site (Figure 3D and Supplementary Figure S3F). Chaol richness estimates ranged from 4 - 43 OTUs for each sample. Overall, there were 13 OTUs that were found in all four sampling regions. Thirty-three OTUs were only found at one sampling region. A majority of the OTUs were closely related to sequences from Rothwald National Reserve forest soil (Pester et al., 2014) (Figure 6 and Supplementary Table S7). Six OTUs were closely related to sequences from an enrichment culture initiated from a wastewater treatment plant (BS10, KC884937) (Pester et al., 2014). Two OTUs clustered with Nitrospira defluvii, enriched from activated sludge. Several $n \times r B$ OTUs clustered with 'Candidatus Nitrospira inopinata' (89.3\% pairwise sequence identity) and 'Candidatus Nitrospira nitrosa' (91.6\% pairwise sequence identity), organisms recently implicated in the complete nitrification of ammonia to nitrite (comammox) (Daims et al., 2015; van Kessel et al., 2015). However, the exact phylogenetic placement of these OTUs varied slightly based on the maximum likelihood algorithm used. Nine OTUs clustered independently on the phylogenetic tree, and had low sequence identity $(<85 \%)$ to $n \times r B$ database sequences.

Nitrobacter $16 \mathrm{~S}$ rRNA gene sequence analyses revealed that one OTU was closely related ( $99 \%$ sequence identity) to sequences from a municipal wastewater Nitrobacter clone. One Nitrobacter OTU was also present in another Iron Springs sample used as technical sequencing replicate, as well as other OTUs with low read counts (2-69 per OTU). Nitrobacter sequences were not further analyzed due to the low number of sequences and samples with hits.

\section{Correlation with Environmental Parameters}

For each nitrification gene dataset (AOA amoA, AOB $16 \mathrm{~S}$ rRNA, Nitrospira $n x r B$ ), we evaluated the relationship between environmental parameters and the total gene abundances (qPCR), relative gene abundance for individual OTUs (based on gene sequence counts), and overall community composition
(CCA of relative gene abundance). All correlation analyses used corrected $p$-values to account for the large number of comparisons.

Though $\mathrm{pH}$ levels varied significantly across all Iron Springs sites (ranging from 3.2-8.3), $\mathrm{pH}$ was not strongly correlated to the overall community structure or relative abundance of individual OTUs for any gene (based on CCA and Spearman correlation). $\mathrm{pH}$ was positivity correlated to the total abundance (qPCR) of AOB 16S rRNA genes, but not for any other genes (Supplementary Table S8).

The high concentrations of heavy metals in the Iron Springs sediments were not correlated with the overall nitrifier community composition or abundance (based on CCA and Spearman correlations). Nonetheless, the relative abundances of several individual Nitrospira $n \times r B$ and AOB 16 S rRNA OTUs, as well as one archaeal amoA OTU, were negatively correlated with metals including $\mathrm{Mn}, \mathrm{Zn}, \mathrm{Sr}$ and $\mathrm{Pb}$ (Supplementary Table S9). At the same time, the relative abundance of other Nitrospira $n x r B$, archaeal amoA, and AOB $16 \mathrm{~S}$ rRNA OTUs was positively correlated with $\mathrm{Mn}$ and $\mathrm{Cu}$ (Supplementary Table S9).

Temperature, which ranged from $7.1-21.2^{\circ} \mathrm{C}$ across the sites, was a strong predictor of the AOB $16 \mathrm{~S}$ rRNA community structure. CCA showed that the overall composition of the AOB 16S rRNA community was strongly correlated with temperature (Supplementary Figure S4). Total AOB 16S rRNA gene abundances (qPCR) were negatively correlated with temperature (Supplementary Table S8). Temperature was positively correlated to the relative abundance of three individual AOB 16S rRNA OTUs (OTU 3, 7, and 16). Temperature was negatively correlated to the relative abundance of one Nitrospira nxrB OTUs (OTU 28) (Supplementary Table S9).

The Nitrospira $n \times r B$ community structure was correlated with conductivity or conductivity-related ions (e.g., $\mathrm{Na}, \mathrm{Ca}, \mathrm{Mg}$ ) in several ways. CCA showed that the overall composition of the AOB 16S rRNA and Nitrospira $n x r B$ communities was strongly correlated with conductivity (Supplementary Figure S4). The relative abundance of several individual Nitrospira $n \times r B$ was negatively correlated with conductivity or conductivity-related ions, and one Nitrospira $n \times r B$ OTU (OTU 1) was positively correlated with Ca (Supplementary Table S9). Sodium was also correlated with the overall composition of the AOB 16S rRNA genes (CCA, Supplementary Figure S4).

\section{DISCUSSION}

Acid mine drainage is a serious threat to freshwater systems and can devastate a river and its aquatic life through its acidic $\mathrm{pH}$ and high metal concentrations. In this study, we determined the abundance and diversity of $\mathrm{AOA}, \mathrm{AOB}$, and $\mathrm{NOB}$ gene sequences through DNA-based analyses in AMD-impacted sediments at the Iron Springs Mining District. The abundance and diversity of $\mathrm{AOA}, \mathrm{AOB}$, and $\mathrm{NOB}$ genes in these AMD-impacted sediments may suggest the potential for nitrification activity.

Low $\mathrm{pH}$ presents physiological challenges to nitrifying microbes through reduced bioavailability of ammonia and nitrite (Suzuki et al., 1974; Stein et al., 1997). Nitrification is thought 


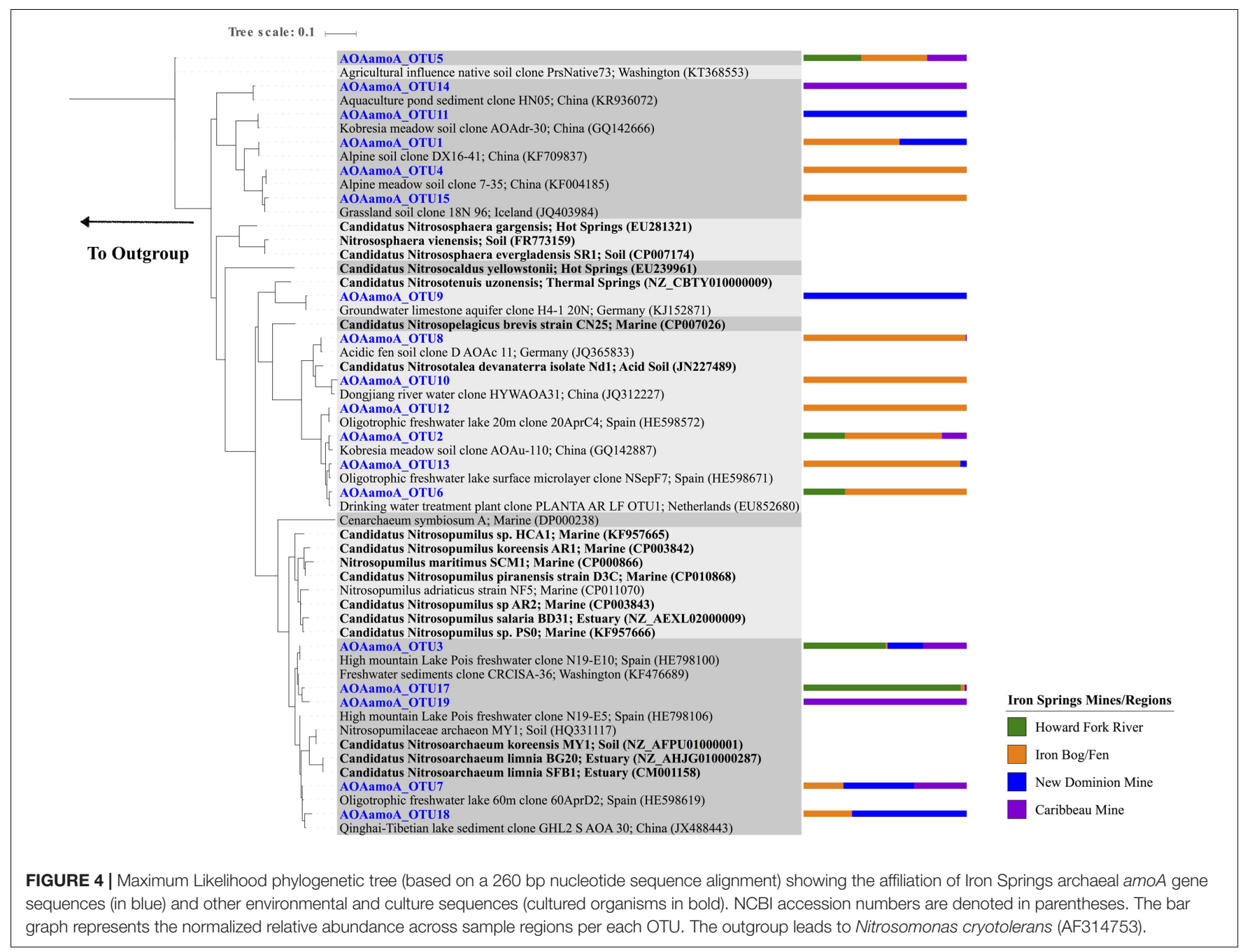

to be energetically challenging at low $\mathrm{pH}$ because ammonia $\left(\mathrm{NH}_{3}\right)$ and nitrite $\left(\mathrm{NO}_{2}{ }^{-}\right)$concentrations are very low due to the chemical equilibrium in solution $\left(\mathrm{NH}_{3}+\mathrm{H}^{+} \rightarrow \mathrm{NH}_{4}{ }^{+}\right.$, $\mathrm{pKa}$ 9.24; $\mathrm{NO}_{2}{ }^{-}+\mathrm{H}^{+} \rightarrow \mathrm{HNO}_{2}$, $\mathrm{pKa} \sim 3.39$ ). At low $\mathrm{pH}$, the number of protons in solution increases and the equilibrium is shifted away from the energetic substrate (ammonia and nitrite). Here, AOA amoA and Nitrospira $n \times r B$ genes were present at most sites and time points regardless of $\mathrm{pH}$. Archaeal amoA and Nitrospira $n \times r B$ gene abundances were high $\left(10^{3}-10^{7}\right.$ copies per $\mu \mathrm{g}$ DNA) at sites with $\mathrm{pH} \leq 4.5$, and genes were detected at sites with $\mathrm{pH}$ as low as 3.5. Because $\mathrm{pH}$ reduces the bioavailability of ammonia, acidic habitats may favor AOA dominance over $\mathrm{AOB}$ due to their high affinity for ammonia (Martens-Habbena et al., 2009; Offre et al., 2014). Alternatively, it was recently proposed that some AOA might possess ammonium transporters instead of ammonia transporters found in $\mathrm{AOB}$ (Offre et al., 2014; Lehtovirta-Morley et al., 2016). Similarly, substrate availability and enzyme activity for nitrite oxidation are reduced as the $\mathrm{pH}$ decreases (Tanaka et al., 1983) often leading to greater $\mathrm{NOB}$ abundance at higher $\mathrm{pH}$ conditions. $\mathrm{AOA}$ and $\mathrm{NOB}$ could have additional mechanisms of adaptation to low $\mathrm{pH}$, such as increased ureolytic activity, proton efflux proteins, proton consuming metabolisms, and cytoplasmic proteins with buffering capacity. The mixotrophic lifestyle of some nitrifiers (e.g., lithoand organotrophy; Hatzenpichler, 2012) may afford an additional means of overcoming energetic stress under low $\mathrm{pH}$ conditions through the utilization of alternate electron sources.

Metal concentrations (e.g., $\mathrm{Al}, \mathrm{Cu}, \mathrm{Fe}$, and $\mathrm{Zn}$ ) at all of the sites exceeded the allowable concentrations as determined by the Colorado Department of Public Health and Environment (CDPHE) Regulation 31. Sites with $\mathrm{pH}<4$ had the highest concentrations of metals, perhaps because low $\mathrm{pH}$ can increase metal dissolution. Heavy metals are known to inhibit nitrification in some systems (Cela and Sumner, 2002; Yan et al., 2013); yet, we found high numbers of $\mathrm{AOA}, \mathrm{AOB}$, and $\mathrm{NOB}$ genes at sites with high metal concentrations. The relative abundance of some individual OTUs was negatively correlated with $\mathrm{Mn}, \mathrm{Zn}, \mathrm{Sr}$ and $\mathrm{Pb}$, while other OTUs were positively correlated with $\mathrm{Mn}$. One archaeal amoA OTU was positively correlated with copper, which is heavily involved in ammonia oxidation and electron transport for AOA (Walker et al., 2010). Specific metals did not equally impact gene abundances of $\mathrm{AOA}, \mathrm{AOB}$, or $\mathrm{NOB}$, possibly 


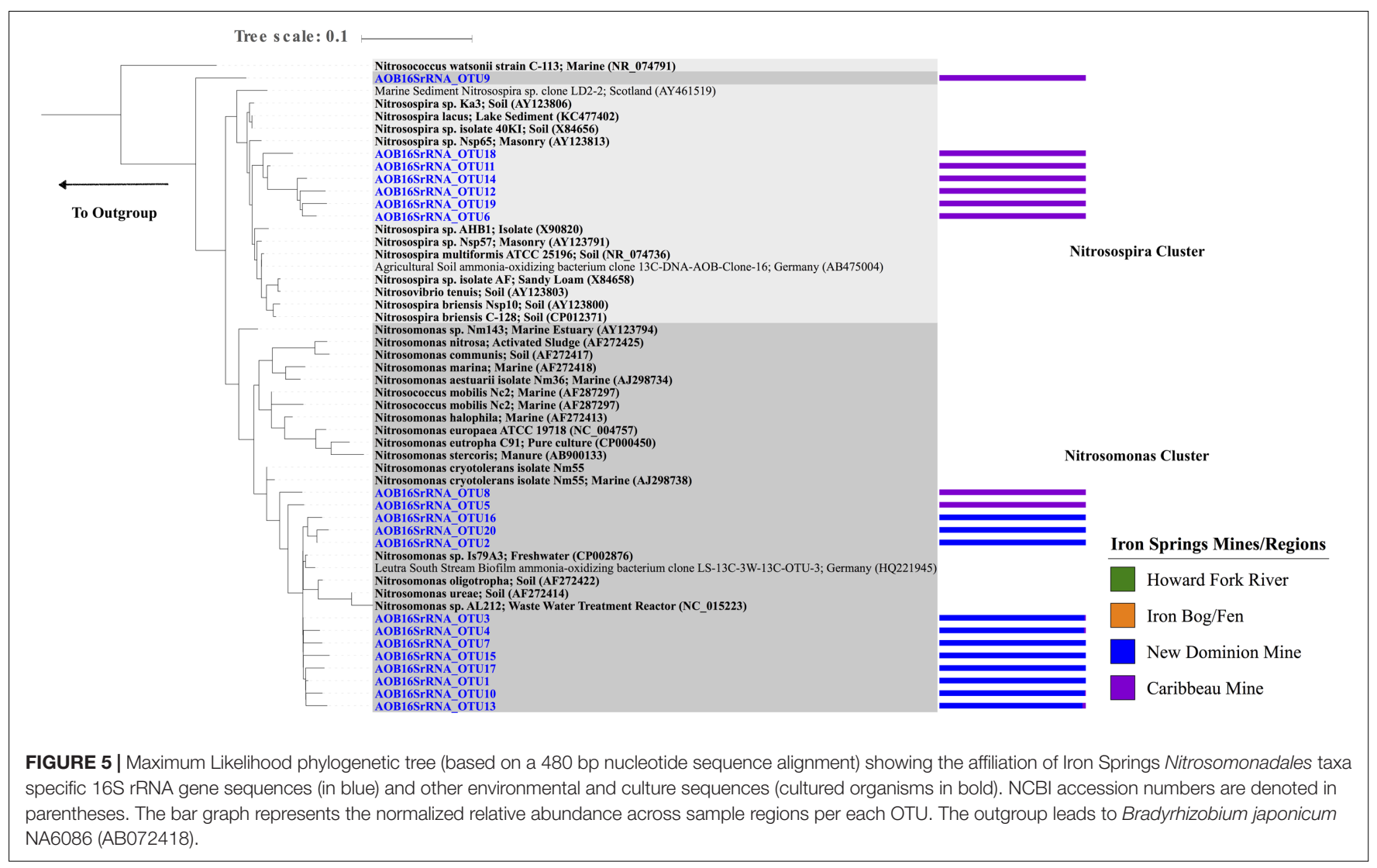

suggesting that metals have different effects on each of these groups as seen in previous studies (Li et al., 2009; Subrahmanyam et al., 2014; Ouyang et al., 2016). For instance, Mn was negatively correlated with some AOB OTUs, positively correlated with some NOB OTUs, and showed no correlation with AOA OTUs. Other previous studies showed decreased abundance or changes in community composition with increasing metal concentrations (Mertens et al., 2006; Principi et al., 2008; Li et al., 2009; Cao et al., 2011). Though metal resistance genes have been found in some nitrifiers (Stein et al., 2007; Starkenburg et al., 2008; Lücker et al., 2010; Spang et al., 2012), it is currently unknown whether these nitrifiers have specific adaptations to tolerate high metal concentrations (e.g., siderophore production, extracellular sequestration, ATP-dependent efflux systems).

Nitrifier gene abundance showed interesting patterns in the Iron Springs mining region. Gene abundance showed a clear seasonal pattern: $\mathrm{AOA}, \mathrm{AOB}$, and $\mathrm{NOB}$ genes were more abundant in late summer than in early summer $(\sim 5$ times more abundant in late summer for $\sim 80 \%$ of samples where abundance was measured in both time points for a given year). Overall, AOA were more abundant than AOB across most sample regions irrespective of varying environmental conditions, which may be due to differences in AOA and AOB physiology. Nitrospira nitrite oxidizers were also abundant across all sample regions. When ammonia oxidizers and nitrite oxidizers were compared together, we observed that the Nitrospira $n x r B$ genes were more abundant than archaeal $a m o A$ and AOB 16 S rRNA genes at many sites (Figure 2). However, gene copy numbers vary for each organism: AOA have one amoA copy per cell, AOB have one 16S rRNA copy per cell, and Nitrospira have 2-6 nxrB copies per cell (Klappenbach et al., 2001; Lücker et al., 2010; Hatzenpichler, 2012; Pester et al., 2014). At a number of sites, we observed either no amplification or non-specific amplification (for archaeal amo A, AOB 16S rRNA, and Nitrospira nxrB), possibly suggesting that $\mathrm{AOA}, \mathrm{AOB}$ and $\mathrm{NOB}$ were absent in those selected sites, present in low numbers, or did not properly amplify with the PCR primers. Further analyses would be necessary to confirm low nitrifier abundance and its ecological implications (e.g., accumulation of ammonia, decreased denitrification, changes in $\mathrm{N}_{2} \mathrm{O}$ emissions).

The overall bacterial 16S rRNA gene community structure in Iron Springs sediments was similar to microbial communities observed in other AMD environments (Volant et al., 2014; Méndez-García et al., 2015), but very little is known about the community structure of nitrifying microbes in AMD environments. In this study, the richness (numbers of observed OTUs) and phylogenetic diversity of the AOA, AOB, and $\mathrm{NOB}$ communities was comparable to other more moderate environments (e.g., uncontaminated soils or freshwater systems). Regions with acidic $\mathrm{pH}$ had several AOA OTUs related to Nitrosotalea associated with acidic soil environments (Figure 4) (Lehtovirta-Morley et al., 2011; Gubry-Rangin et al., 2011; Pester et al., 2012), which may suggest that these AOA are adapted to acidic $\mathrm{pH}$ conditions. Many of the OTUs found in the Howard 


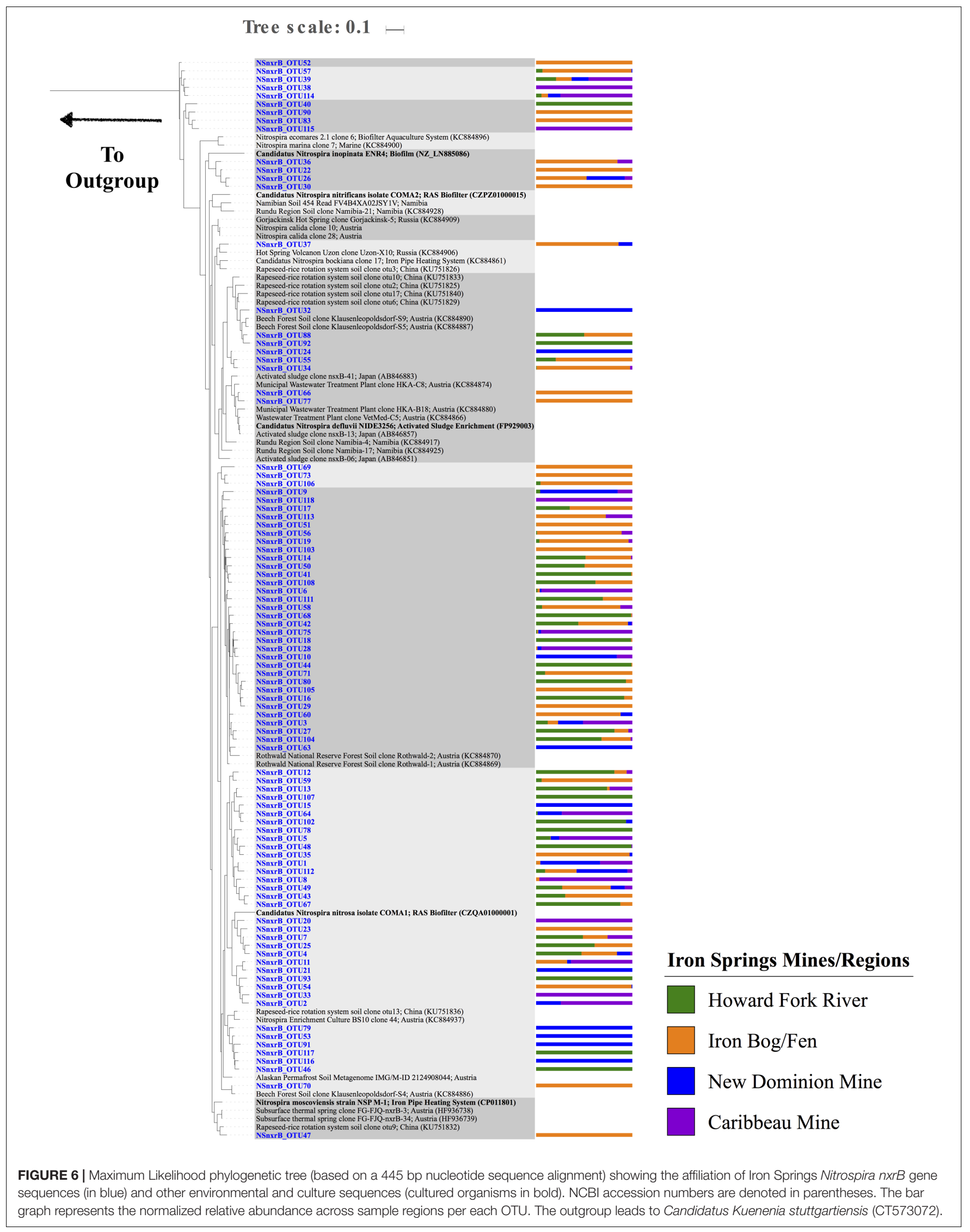


Fork River and Caribbeau Mine sites (more neutral pH) were associated with freshwater sequences (van der Wielen et al., 2009; Auguet et al., 2012; Mosier et al., 2012; Auguet and Casamayor, 2013).

Ammonia-oxidizing bacteria observed in these AMDimpacted sites belonged to the family Nitrosomonadaceae, which are generally well distributed in both terrestrial and aquatic environments (Stein et al., 2007; Norton et al., 2008; Zheng et al., 2013) (Figure 5). The majority of OTUs dominating the Caribbeau Mine region clustered with Nitrosospira found in soil environments (Utåker et al., 1995; Jiang and Bakken, 1999; Purkhold et al., 2003; Norton et al., 2008). On the other hand, OTUs dominating the New Dominion Mine region belonged only to the Nitrosomonas cluster and were closely related to Nitrosomonas sp. Is79A3 usually found at sites with low ammonia concentrations (Bollmann et al., 2013). These findings could suggest that the AOB in the New Dominion Mine may be adapted to low substrate availability (ammonia), possibly a result of the low $\mathrm{pH}$ compared to the Caribbeau Mine.

NOB in these AMD-impacted sites were related to phylogenetically diverse Nitrospira species. Nitrobacter NOB genes did not amplify well in the AMD-impacted sediments (no qPCR amplification with several 16S rRNA and $n x r B$ gene primer sets, and only a very small number of OTUs present in the sequence dataset). Although Nitrobacter are typically observed along with Nitrospira in aquatic systems, Nitrospira are often numerically dominant in sediments (Altmann et al., 2004; Cébron and Garnier, 2005; Freitag et al., 2006; Satoh et al., 2007) and water treatment plants (Juretschko et al., 1998; Daims et al., 2001; Huang et al., 2010). These findings may suggest that Nitrobacter are less tolerant of the harsh conditions in this system (low $\mathrm{pH}$ and high metals), that the available primer sets do not amplify the particular Nitrobacter found at these sites, or that biases in DNA extraction or PCR amplification prevented recovery of Nitrobacter sequences.

\section{CONCLUSION}

In summary, we found interesting patterns of gene abundance and diversity of $\mathrm{AOA}, \mathrm{AOB}$, and $\mathrm{NOB}$ in $\mathrm{AMD}$-impacted sediments with low $\mathrm{pH}$ and high metal concentrations. Sediment $\mathrm{pH}$ was correlated with the total abundance of AOB 16S rRNA genes, but not the total abundance of archaeal amoA or Nitrospira $n \times r B$ genes, or to the overall community structure or relative abundance of individual OTUs for any gene. Heavy metals, which had high concentrations in the Iron Springs sediments, were

\section{REFERENCES}

Aakra, A., Utaker, J. B., and Nes, I. F. (1999). RFLP of rRNA genes and sequencing of the 16S-23S rDNA intergenic spacer region of ammonia-oxidizing bacteria: a phylogenetic approach. Int. J. Syst. Bacteriol. 49, 123-130. doi: 10.1099/ 00207713-49-1-123

Altmann, D., Stief, P., Amann, R., and de Beer, D. (2004). Nitrification in freshwater sediments as influenced by insect larvae: quantification by microsensors and fluorescence in situ hybridization. Microb. Ecol. 48, 145-153. doi: 10.1007/ s00248-003-2015-6 correlated with the relative abundances of several individual OTUs, but not the overall nitrifier community composition or abundance. It is important to note that many other factors not measured here could impact nitrification, including other chemical variables or organismal interactions. In addition, the combined effect of multiple, simultaneous stresses (e.g., acidic $\mathrm{pH}$ along with a suite of metals) on gene abundance and community composition is difficult to tease apart. This study provides a foundation for future work to determine rates of nitrification and the role of comammox bacteria in this AMD-impacted system, and to cultivate acidophilic and metal-tolerant AOA and NOB.

\section{AUTHOR CONTRIBUTIONS}

Conceived and designed the experiments: AM and TR. Sampling, site information, and chemistry: TR. Performed the experiments: BR. Analyzed the data: BR, AB, TR, and AM. Contributed to the manuscript: BR, AB, TR, and AM. Funded the research: AM and TR.

\section{FUNDING}

This publication was made possible through data from the Iron Springs Project, which was collected and analyzed by the US. Environmental Protection Agency, and through funding provided by the US. Department of Agriculture, Forest Service (to TR) and by the University of Colorado, Denver (to AM). USDA is an equal opportunity employer, provider and lender.

\section{ACKNOWLEDGMENTS}

We thank Joshua Sackett and Ashley Joslin for assistance with sample collection and DNA extraction. We thank Robert Edgar, Sladjana Subotic, and Adrienne Narrowe for guidance on bioinformatic data analyses. Portions of this manuscript were previously published and copyrighted as a part of University of Colorado Denver Master's thesis submission (BR, 2016).

\section{SUPPLEMENTARY MATERIAL}

The Supplementary Material for this article can be found online at: https://www.frontiersin.org/articles/10.3389/fmicb. 2017.02136/full\#supplementary-material

Auguet, J.-C., and Casamayor, E. O. (2013). Partitioning of Thaumarchaeota populations along environmental gradients in high mountain lakes. FEMS Microbiol. Ecol. 84, 154-164. doi: 10.1111/1574-6941. 12047

Auguet, J.-C., Triadó-Margarit, X., Nomokonova, N., Camarero, L., and Casamayor, E. O. (2012). Vertical segregation and phylogenetic characterization of ammonia-oxidizing Archaea in a deep oligotrophic lake. ISME J. 6, 1786-1797. doi: 10.1038/ismej.2012.33

Beman, J., Chow, C., King, A., Feng, Y., Fuhrman, J., Andersson, A., et al. (2011). Global declines in oceanic nitrification rates as a consequence of ocean 
acidification. Proc. Natl. Acad. Sci. U.S.A. 108, 208-213. doi: 10.1073/pnas. 1011053108

Blackburne, R., Vadivelu, V. M., Yuan, Z., and Keller, J. (2007). Kinetic characterisation of an enriched Nitrospira culture with comparison to Nitrobacter. Water Res. 41, 3033-3042. doi: 10.1016/j.watres.2007.01.043

Bollmann, A., Sedlacek, C. J., Norton, J., Laanbroek, H. J., Suwa, Y., Stein, L. Y., et al. (2013). Complete genome sequence of Nitrosomonas sp. Is79, an ammonia oxidizing bacterium adapted to low ammonium concentrations. Stand. Genomic Sci. 7, 469-482. doi: 10.4056/sigs.3517166

Broberg, A. (1984). Effects of Heavy Metals on Certain Microbial Processes in Freshwater Sediments. Doctoral dissertation, Uppsala University, Uppsala.

Cao, H., Li, M., Hong, Y., and Gu, J.-D. (2011). Diversity and abundance of ammonia-oxidizing archaea and bacteria in polluted mangrove sediment. Syst. Appl. Microbiol. 34, 513-523. doi: 10.1016/j.syapm.2010.11.023

Caporaso, J. G., Kuczynski, J., Stombaugh, J., Bittinger, K., Bushman, F. D., Costello, E. K., et al. (2010). QIIME allows analysis of high-throughput community sequencing data. Nat Methods 7, 335-336. doi: 10.1038/nmeth.f.303

Cébron, A., and Garnier, J. (2005). Nitrobacter and Nitrospira genera as representatives of nitrite-oxidizing bacteria: detection, quantification and growth along the lower Seine River (France). Water Res. 39, 4979-4992. doi: 10.1016/j.watres.2005.10.006

Cela, S., and Sumner, M. E. (2002). Critical concentrations of copper, nickel, lead, and cadmium in soils based on nitrification. Commun. Soil Sci. Plant Anal. 33 19-30. doi: 10.1081/CSS-120002374

Daims, H., Lebedeva, E. V., Pjevac, P., Han, P., Herbold, C., Albertsen, M., et al. (2015). Complete nitrification by Nitrospira bacteria. Nature 528, 504-509. doi: $10.1038 /$ nature16461

Daims, H., Nielsen, J. L., Nielsen, P. H., Schleifer, K. H., and Wagner, M. (2001). In situ characterization of Nitrospira-like nitrite-oxidizing bacteria active in wastewater treatment plants. Appl. Environ. Microbiol. 67, 5273-5284. doi: 10.1128/AEM.67.11.5273-5284.2001

Degrange, V., and Bardin, R. (1995). Detection and counting of Nitrobacter populations in soil by PCR. Appl. Environ. Microbiol. 61, 2093-2098.

DeSantis, T. Z., Hugenholtz, P., Larsen, N., Rojas, M., Brodie, E. L., Keller, K., et al. (2006). Greengenes, a chimera-checked 16S rRNA gene database and workbench compatible with ARB. Appl. Environ. Microbiol. 72, 5069-5072. doi: 10.1128/AEM.03006-05

Edgar, R. C. (2013). UPARSE: highly accurate OTU sequences from microbial amplicon reads. Nat. Methods 10, 996-998. doi: 10.1038/nmeth.2604

Ehrich, S., Behrens, D., Lebedeva, E., Ludwig, W., and Bock, E. (1995). A new obligately chemolithoautotrophic, nitrite-oxidizing bacterium, Nitrospira moscoviensis sp. nov. and its phylogenetic relationship. Arch. Microbiol. 164, 16-23. doi: 10.1007/BF02568729

Francis, C. A., Roberts, K. J., Beman, J. M., Santoro, A. E., and Oakley, B. B. (2005). Ubiquity and diversity of ammonia-oxidizing archaea in water columns and sediments of the ocean. Proc. Natl. Acad. Sci. U.S.A. 102, 14683-14688. doi: 10.1073/pnas.0506625102

Freitag, T. E., Chang, L., and Prosser, J. I. (2006). Changes in the community structure and activity of betaproteobacterial ammonia-oxidizing sediment bacteria along a freshwater-marine gradient. Environ. Microbiol. 8, 684-696. doi: 10.1111/j.1462-2920.2005.00947.x

Graham, D. W., Knapp, C. W., Van Vleck, E. S., Bloor, K., Lane, T. B., and Graham, C. E. (2007). Experimental demonstration of chaotic instability in biological nitrification. ISME J. 1, 385-393. doi: 10.1038/ismej.2007.45

Grunditz, C., and Dalhammar, G. (2001). Development of nitrification inhibition assays using pure cultures of Nitrosomonas and Nitrobacter. Water Res. 35, 433-440. doi: 10.1016/S0043-1354(00)00312-2

Gubry-Rangin, C., Hai, B., Quince, C., Engel, M., Thomson, B. C., James, P., et al. (2011). Niche specialization of terrestrial archaeal ammonia oxidizers. Proc. Natl. Acad. Sci. U.S.A. 108, 21206-21211. doi: 10.1073/pnas.1109000108

Gubry-Rangin, C., Nicol, G. W., and Prosser, J. I. (2010). Archaea rather than bacteria control nitrification in two agricultural acidic soils. FEMS Microbiol. Ecol. 74, 566-574. doi: 10.1111/j.1574-6941.2010.00971.x

Hallam, S. J., Konstantinidis, K. T., Putnam, N., Schleper, C., Watanabe, Y.I., Sugahara, J., et al. (2006). Genomic analysis of the uncultivated marine crenarchaeote Cenarchaeum symbiosum. Proc. Natl. Acad. Sci. U.S.A. 103, 18296-18301. doi: $10.1073 /$ pnas. 0608549103
Hatzenpichler, R. (2012). Diversity, physiology, and niche differentiation of ammonia-oxidizing archaea. Appl. Environ. Microbiol. 78, 7501-7510. doi: 10.1128/AEM.01960-12

He, J.-Z., Hu, H. W., and Zhang, L.-M. (2012). Current insights into the autotrophic thaumarchaeal ammonia oxidation in acidic soils. Soil Biol. Biochem. 55, 146-154. doi: 10.1016/j.soilbio.2012.06.006

He, J.-Z., Shen, J.-P., Zhang, L.-M., Zhu, Y.-G., Zheng, Y.-M., Xu, M.-G., et al. (2007). Quantitative analyses of the abundance and composition of ammoniaoxidizing bacteria and ammonia-oxidizing archaea of a Chinese upland red soil under long-term fertilization practices. Environ. Microbiol. 9, 2364-2374. doi: $10.1111 / j .1462-2920.2007 .01358 . x$

Hermansson, A., and Lindgren, P. E. (2001). Quantification of ammonia-oxidizing bacteria in arable soil by real-time PCR. Appl. Environ. Microbiol. 67, 972-976. doi: 10.1128/AEM.67.2.972-976.2001

Herrmann, M., Hädrich, A., and Küsel, K. (2012). Predominance of thaumarchaeal ammonia oxidizer abundance and transcriptional activity in an acidic fen. Environ. Microbiol. 14, 3013-3025. doi: 10.1111/j.1462-2920.2012.02882.x

Hu, H. W., Zhang, L.-M., Dai, Y., Di, H.-J., and He, J.-Z. (2013). pH-dependent distribution of soil ammonia oxidizers across a large geographical scale as revealed by high-throughput pyrosequencing. J. Soils Sediments 13, 1439-1449. doi: 10.1007/s11368-013-0726-y

Huang, Z., Gedalanga, P. B., and Olson, B. H. (2010). Distribution of Nitrobacter and Nitrospira communities in an aerobic activated sludge bioreactor and their contributions to nitrite oxidation. Proc. Water Environ. Fed. 2010, 2390-2403. doi: 10.1016/j.watres.2010.05.037

Huesemann, M. H., Skillman, A. D., and Crecelius, E. A. (2002). The inhibition of marine nitrification by ocean disposal of carbon dioxide. Mar. Pollut. Bull. 44, 142-148. doi: 10.1016/S0025-326X(01)00194-1

Jiang, Q., and Bakken, L. (1999). Comparison of Nitrosospira strains isolated from terrestrial environments. FEMS Microbiol. Ecol. 30, 171-186. doi: 10.1111/j. 1574-6941.1999.tb00646.x

Jiménez, E., Giménez, J. B., Ruano, M. V., Ferrer, J., and Serralta, J. (2011). Effect of $\mathrm{pH}$ and nitrite concentration on nitrite oxidation rate. Bioresour. Technol. 102, 8741-8747. doi: 10.1016/j.biortech.2011.07.092

Juretschko, S., Timmermann, G., Schmid, M., Schleifer, K. H., PommereningRoser, A., Koops, H. P., et al. (1998). Combined molecular and conventional analyses of nitrifying bacterium diversity in activated sludge: Nitrosococcus mobilis and Nitrospira-like bacteria as dominant populations. Appl. Environ. Microbiol. 64, 3042-3051.

Kearse, M., Moir, R., Wilson, A., Stones-Havas, S., Cheung, M., Sturrock, S., et al. (2012). Geneious Basic: an integrated and extendable desktop software platform for the organization and analysis of sequence data. Bioinformatics 28 , 1647-1649. doi: 10.1093/bioinformatics/bts199

Klappenbach, J. A., Saxman, P., Cole, J. R., and Schmidt, T. M. (2001). rrndb - the Ribosomal RNA operon copy number database. Nucleic Acids Res. 29, 181-184. doi: $10.1093 /$ nar/29.1.181

Kowalchuk, G. A., and Stephen, J. R. (2001). Ammonia-oxidizing bacteria: a model for molecular microbial ecology. Annu. Rev. Microbiol. 55, 485-529. doi: 10.1146/annurev.micro.55.1.485

Kowalchuk, G. A., Stephen, J. R., De Boer, W., Prosser, J. I., Embley, T. M., and Woldendorp, J. W. (1997). Analysis of ammonia-oxidizing bacteria of the beta subdivision of the class Proteobacteria in coastal sand dunes by denaturing gradient gel electrophoresis and sequencing of PCR-amplified 16S ribosomal DNA fragments. Appl. Environ. Microbiol. 63, 1489-1497.

Lehtovirta-Morley, L. E., Ge, C., Ross, J., Yao, H., Nicol, G. W., and Prosser, J. I. (2014). Characterisation of terrestrial acidophilic archaeal ammonia oxidisers and their inhibition and stimulation by organic compounds. FEMS Microbiol. Ecol. 89, 542-552. doi: 10.1111/1574-6941.12353

Lehtovirta-Morley, L. E., Sayavedra-Soto, L. A., Gallois, N., Schouten, S., Stein, L. Y., Prosser, J. I., et al. (2016). Identifying potential mechanisms enabling acidophily in the ammonia-oxidizing archaeon "Candidatus Nitrosotalea devanaterra”. Appl. Environ. Microbiol. 82, 2608-2619. doi: 10.1128/AEM. 04031-15

Lehtovirta-Morley, L. E., Stoecker, K., Vilcinskas, A., Prosser, J. I., and Nicol, G. W. (2011). Cultivation of an obligate acidophilic ammonia oxidizer from a nitrifying acid soil. Proc. Natl. Acad. Sci. U.S.A. 108, 15892-15897. doi: 10.1073/ pnas. 1107196108 
Letunic, I., and Bork, P. (2016). Interactive tree of life (iTOL) v3: an online tool for the display and annotation of phylogenetic and other trees. Nucleic Acids Res. 44, W242-W245. doi: 10.1093/nar/gkw290

Li, X., Zhu, Y.-G., Cavagnaro, T. R., Chen, M., Sun, J., Chen, X., et al. (2009). Do ammonia-oxidizing archaea respond to soil $\mathrm{Cu}$ contamination similarly as ammonia-oxidizing bacteria? Plant Soil 324, 209-217. doi: 10.1007/s11104009-9947-7

Lu, L., and Jia, Z. (2013). Urease gene-containing Archaea dominate autotrophic ammonia oxidation in two acid soils. Environ. Microbiol. 15, 1795-1809. doi: 10.1111/1462-2920.12071

Lucheta, A. R., Otero, X. L., Macías, F., and Lambais, M. R. (2013). Bacterial and archaeal communities in the acid pit lake sediments of a chalcopyrite mine. Extremophiles 17, 941-951. doi: 10.1007/s00792-013-0576-y

Lücker, S., Wagner, M., Maixner, F., Pelletier, E., Koch, H., Vacherie, B., et al. (2010). A Nitrospira metagenome illuminates the physiology and evolution of globally important nitrite-oxidizing bacteria. Proc. Natl. Acad. Sci. U.S.A. 107, 13479-13484. doi: 10.1073/pnas.1003860107

Ludwig, W. (2004). ARB: a software environment for sequence data. Nucleic Acids Res. 32, 1363-1371. doi: 10.1093/nar/gkh293

Martens-Habbena, W., Berube, P. M., Urakawa, H., la Torre de, J. R., and Stahl, D. A. (2009). Ammonia oxidation kinetics determine niche separation of nitrifying Archaea and Bacteria. Nature 461, 976-979. doi: 10.1038/nature08465

Méndez-García, C., Peláez, A. I., Mesa, V., Sánchez, J., Golyshina, O. V., and Ferrer, M. (2015). Microbial diversity and metabolic networks in acid mine drainage habitats. Front. Microbiol. 6:475. doi: 10.3389/fmicb.2015.00475

Mertens, J., Broos, K., Wakelin, S. A., Kowalchuk, G. A., Springael, D., and Smolders, E. (2009). Bacteria, not archaea, restore nitrification in a zinccontaminated soil. ISME J. 3, 916-923. doi: 10.1038/ismej.2009.39

Mertens, J. J., Springael, D. D., De Troyer, I. I., Cheyns, K. K., Wattiau, P. P., and Smolders, E. E. (2006). Long-term exposure to elevated zinc concentrations induced structural changes and zinc tolerance of the nitrifying community in soil. Environ. Microbiol. 8, 2170-2178. doi: 10.1111/j.1462-2920.2006. 01100.x

Mosier, A. C., Allen, E. E., Kim, M., Ferriera, S., and Francis, C. A. (2012). Genome sequence of 'Candidatus Nitrosoarchaeum limnia' BG20, a low-salinity ammonia-oxidizing archaeon from the San Francisco Bay estuary. J. Bacteriol. 194, 2119-2120. doi: 10.1128/JB.00007-12

Mosier, A. C., and Francis, C. A. (2008). Relative abundance and diversity of ammonia-oxidizing archaea and bacteria in the San Francisco Bay estuary. Environ. Microbiol. 10, 3002-3016. doi: 10.1111/j.1462-2920.2008.01764.x

Nash, J. T. (2002). Hydrogeochemical Investigations of Historic Mining Districts, Central Western Slope of Colorado, Including Influence on Surface-Water Quality. Reston, VA: Geological Survey (USGS).

Nicol, G. W., Leininger, S., Schleper, C., and Prosser, J. I. (2008). The influence of soil $\mathrm{pH}$ on the diversity, abundance and transcriptional activity of ammonia oxidizing archaea and bacteria. Environ. Microbiol. 10, 2966-2978. doi: 10.1111/ j.1462-2920.2008.01701.x

Niyogi, D. K., Lewis, W. M. Jr., and McKnight, D. M. (2003). Direct and indirect effects of mine drainage on bacterial processes in mountain streams. J. N. Am. Benthol. Soc. 22, 276-291. doi: 10.2307/1467998

Norton, J. M., Klotz, M. G., Stein, L. Y., Arp, D. J., Bottomley, P. J., Chain, P. S. G., et al. (2008). Complete genome sequence of Nitrosospira multiformis, an ammonia-oxidizing bacterium from the soil environment. Appl. Environ. Microbiol. 74, 3559-3572. doi: 10.1128/AEM.02722-07

Offre, P., Kerou, M., Spang, A., and Schleper, C. (2014). Variability of the transporter gene complement in ammonia-oxidizing archaea. Trends Microbiol. 22, 665-675. doi: 10.1016/j.tim.2014.07.007

Ouyang, F., Zhai, H., Ji, M., Zhang, H., and Dong, Z. (2016). Physiological and transcriptional responses of nitrifying bacteria exposed to copper in activated sludge. J. Hazard. Mater. 301, 172-178. doi: 10.1016/j.jhazmat.2015.08.039

Parada, A. E., Needham, D. M., and Fuhrman, J. A. (2016). Every base matters: assessing small subunit rRNA primers for marine microbiomes with mock communities, time series and global field samples. Environ. Microbiol. 18, 1403-1414. doi: 10.1111/1462-2920.13023

Pester, M., Maixner, F., Berry, D., Rattei, T., Koch, H., Lücker, S., et al. (2014). $\mathrm{NxrB}$ encoding the beta subunit of nitrite oxidoreductase as functional and phylogenetic marker for nitrite-oxidizing Nitrospira. Environ. Microbiol. 16, 3055-3071. doi: 10.1111/1462-2920.12300
Pester, M., Rattei, T., Flechl, S., Gröngröft, A., Richter, A., Overmann, J., et al. (2012). amoA-based consensus phylogeny of ammonia-oxidizing archaea and deep sequencing of $a m o A$ genes from soils of four different geographic regions. Environ. Microbiol. 14, 525-539. doi: 10.1111/j.1462-2920.2011.02666.x

Price, M. N., Dehal, P. S., and Arkin, A. P. (2010). FastTree 2-approximately maximum-likelihood trees for large alignments. PLOS ONE 5:e9490. doi: 10.1371/journal.pone.0009490

Principi, P., Villa, F., Giussani, B., Zanardini, E., Cappitelli, F., and Sorlini, C. (2008). The effect of copper on the structure of the ammonia-oxidizing microbial community in an activated sludge wastewater treatment plant. Microb. Ecol. 57, 215-220. doi: 10.1007/s00248-008-9432-5

Purkhold, U., Wagner, M., Timmermann, G., Pommerening-Röser, A., and Koops, H.-P. (2003). 16S rRNA and amoA-based phylogeny of 12 novel betaproteobacterial ammonia-oxidizing isolates: extension of the dataset and proposal of a new lineage within the Nitrosomonads. Int. J. Syst. Evol. Microbiol. 53, 1485-1494. doi: 10.1099/ijs.0.02638-0

Rotthauwe, J. H. J., Witzel, K. P. K., and Liesack, W. W. (1997). The ammonia monooxygenase structural gene $a m o A$ as a functional marker: molecular fine-scale analysis of natural ammonia-oxidizing populations. Appl. Environ. Microbiol. 63, 4704-4712.

Rudd, J. W., Kelly, C. A., Schindler, D. W., and Turner, M. A. (1988). Disruption of the nitrogen cycle in acidified lakes. Science 240, 1515-1517. doi: 10.1126/ science.240.4858.1515

Satoh, H., Nakamura, Y., and Okabe, S. (2007). Influences of infaunal burrows on the community structure and activity of ammonia-oxidizing bacteria in intertidal sediments. Appl. Environ. Microbiol. 73, 1341-1348. doi: 10.1128/ AEM.02073-06

Šmilauer, P., and Lepš, J. (2014). Multivariate Analysis of Ecological Data Using CANOCO 5. Cambridge: Cambridge University Press. doi: 10.1017/ CBO9781139627061

Smolders, E., Brans, K., Coppens, F., and Merckx, R. (2001). Potential nitrification rate as a tool for screening toxicity in metal-contaminated soils. Environ. Toxicol. Chem. 20, 2469-2474. doi: 10.1002/etc.5620201111

Sonthiphand, P., Cejudo, E., Schiff, S. L., and Neufeld, J. D. (2013). Wastewater effluent impacts ammonia-oxidizing prokaryotes of the Grand River, Canada. Appl. Environ. Microbiol. 79, 7454-7465. doi: 10.1128/AEM.02202-13

Spang, A., Poehlein, A., Offre, P., Zumbrägel, S., Haider, S., Rychlik, N., et al. (2012). The genome of the ammonia-oxidizing Candidatus Nitrososphaera gargensis: insights into metabolic versatility and environmental adaptations. Environ. Microbiol. 14, 3122-3145. doi: 10.1111/j.1462-2920.2012.02893.x

Starkenburg, S. R., Larimer, F. W., Stein, L. Y., Klotz, M. G., Chain, P. S. G., Sayavedra-Soto, L. A., et al. (2008). Complete genome sequence of Nitrobacter hamburgensis X14 and comparative genomic analysis of species within the genus Nitrobacter. Appl. Environ. Microbiol. 74, 2852-2863. doi: 10.1128/AEM. 02311-07

Stein, L. Y., Arp, D. J., Berube, P. M., Chain, P. S. G., Hauser, L., Jetten, M. S. M., et al. (2007). Whole-genome analysis of the ammonia-oxidizing bacterium, Nitrosomonas eutropha C91: implications for niche adaptation. Environ. Microbiol. 9, 2993-3007. doi: 10.1111/j.1462-2920.2007.01409.x

Stein, L. Y., Arp, D. J., and Hyman, M. R. (1997). Regulation of the synthesis and activity of ammonia monooxygenase in Nitrosomonas europaea by altering $\mathrm{pH}$ to affect NH3 availability. Appl. Environ. Microbiol. 63, 4588-4592.

Stephen, J. R., Chang, Y. J., Macnaughton, S. J., Kowalchuk, G. A., Leung, K. T., Flemming, C. A., et al. (1999). Effect of toxic metals on indigenous soil beta-subgroup proteobacterium ammonia oxidizer community structure and protection against toxicity by inoculated metal-resistant bacteria. Appl. Environ. Microbiol. 65, 95-101.

Stephen, J. R., Kowalchuk, G. A., Bruns, M.-A. V., Phillips, C. J., Embley, T. M., and Prosser, J. I. (1998). Analysis of $\beta$-subgroup proteobacterial ammonia oxidizer populations in soil by denaturing gradient gel electrophoresis analysis and hierarchical phylogenetic probing. Appl. Environ. Microbiol. 64, 2958-2965.

Subrahmanyam, G., Hu, H. W., Zheng, Y.-M., Archana, G., He, J.-Z., and Liu, Y.-R. (2014). Response of ammonia oxidizing microbes to the stresses of arsenic and copper in two acidic alfisols. Appl. Soil Ecol. 77, 59-67. doi: 10.1016/j.apsoil.2014.01.011

Suzuki, I., Dular, U., and Kwok, S. C. (1974). Ammonia or ammonium ion as substrate for oxidation by Nitrosomonas europaea cells and extracts. J. Bacteriol. 120, 556-558. 
Takai, K., and Horikoshi, K. (2000). Rapid detection and quantification of members of the archaeal community by quantitative PCR using fluorogenic probes. Appl. Environ. Microbiol. 66, 5066-5072. doi: 10.1128/AEM.66.11.5066-5072. 2000

Tanaka, Y., Fukumori, Y., and Yamanaka, T. (1983). Purification of cytochrome a $1 \mathrm{c} 1$ from Nitrobacter agilis and characterization of nitrite oxidation system of the bacterium. Arch. Microbiol. 135, 265-271. doi: 10.1007/BF00413479

Utåker, J. B., Bakken, L., Jiang, Q. Q., and Nes, I. F. (1995). Phylogenetic analysis of seven new isolates of ammonia-oxidizing bacteria based on 16S rRNA gene sequences. Syst. Appl. Microbiol. 18, 549-559. doi: 10.1016/S0723-2020(11) 80415-7

van der Wielen, P. W. J. J., Voost, S., and van der Kooij, D. (2009). Ammoniaoxidizing bacteria and archaea in groundwater treatment and drinking water distribution systems. Appl. Environ. Microbiol. 75, 4687-4695. doi: 10.1128/ AEM.00387-09

van Kessel, M. A. H. J., Speth, D. R., Albertsen, M., Nielsen, P. H., Camp den, H. J. M. O., Kartal, B., et al. (2015). Complete nitrification by a single microorganism. Nature 528, 555-559. doi: 10.1038/nature16459

Vanparys, B., Spieck, E., Heylen, K., Wittebolle, L., Geets, J., Boon, N., et al. (2007). The phylogeny of the genus Nitrobacter based on comparative rep-PCR, 16S rRNA and nitrite oxidoreductase gene sequence analysis. Syst. Appl. Microbiol. 30, 297-308. doi: 10.1016/j.syapm.2006.11.006

Volant, A., Bruneel, O., Desoeuvre, A., Héry, M., Casiot, C., Bru, N., et al. (2014). Diversity and spatiotemporal dynamics of bacterial communities: physicochemical and other drivers along an acid mine drainage. FEMS Microbiol. Ecol. 90, 247-263. doi: 10.1111/1574-6941.12394

Volant, A., Desoeuvre, A., Casiot, C., Lauga, B., Delpoux, S., Morin, G., et al. (2012). Archaeal diversity: temporal variation in the arsenic-rich creek sediments of Carnoulès Mine, France. Extremophiles 16, 645-657. doi: 10.1007/s00792-0120466-8

Voytek, M. A., and Ward, B. B. (1995). Detection of ammonium-oxidizing bacteria of the beta-subclass of the class Proteobacteria in aquatic samples with the PCR. Appl. Environ. Microbiol. 61, 1444-1450.
Walker, C. B., la Torre de, J. R., Klotz, M. G., Urakawa, H., Pinel, N., Arp, D. J., et al. (2010). Nitrosopumilus maritimus genome reveals unique mechanisms for nitrification and autotrophy in globally distributed marine crenarchaea. Proc. Natl. Acad. Sci. U.S.A. 107, 8818-8823. doi: 10.1073/pnas.0913533107

Ward, B. B., Arp, D. J., and Klotz, M. G. (2011). Nitrification. Washington, DC: American Society for Microbiology Press.

Wilson, D. O. (1977). Nitrification in three soils amended with zinc sulfate. Soil Biol. Biochem. 9, 277-280. doi: 10.1016/0038-0717(77)90035-9

Wright, E. S., Yilmaz, L. S., and Noguera, D. R. (2012). DECIPHER, a search-based approach to chimera identification for $16 \mathrm{~S}$ rRNA sequences. Appl. Environ. Microbiol. 78, 717-725. doi: 10.1128/AEM.06516-11

Yan, J., Quan, G., and Ding, C. (2013). Effects of the combined pollution of lead and cadmium on soil urease activity and nitrification. Procedia Environ. Sci. 18, 78-83. doi: 10.1016/j.proenv.2013.04.011

Zhang, L.-M., Hu, H. W., Shen, J.-P., and He, J.-Z. (2012). Ammonia-oxidizing archaea have more important role than ammonia-oxidizing bacteria in ammonia oxidation of strongly acidic soils. ISME J. 6, 1032-1045. doi: 10.1038/ ismej.2011.168

Zheng, Y., Hou, L., Liu, M., Lu, M., Zhao, H., Yin, G., et al. (2013). Diversity, abundance, and activity of ammonia-oxidizing bacteria and archaea in Chongming eastern intertidal sediments. Appl. Microbiol. Biotechnol. 97, 8351-8363. doi: 10.1007/s00253-012-4512-3

Conflict of Interest Statement: The authors declare that the research was conducted in the absence of any commercial or financial relationships that could be construed as a potential conflict of interest.

Copyright (C) 2017 Ramanathan, Boddicker, Roane and Mosier. This is an open-access article distributed under the terms of the Creative Commons Attribution License (CC BY). The use, distribution or reproduction in other forums is permitted, provided the original author(s) or licensor are credited and that the original publication in this journal is cited, in accordance with accepted academic practice. No use, distribution or reproduction is permitted which does not comply with these terms. 